\title{
Tüketici Düşmanlığının Ülke İmajı, Ürün Değerlendirme ve Yabancı Ürün Satın Alma İsteğine Etkisi Üzerine Bir Araştırma
}

\author{
Sevgi Ayşe ÖZTÜRK*, Fatma Zeynep ÖZATA** ${ }^{* *}$ Fuat EROL $^{* * *}$
}

Öz

Günümüzde küreselleşmenin de etkisiyle pek çok ülkede ve pek çok ürün grubunda tüketiciler yabancı menşeili ürün seçenekleriyle karşı karşıyadır. Bu durum tüketicilerin yabancı ürünlere yönelik satın alma istekleri, tüketici düşmanlığı ve ülke imajına yönelik pek çok araştırmaya yön vermektedir. Ancak literatürde halen bu yapıların birbirleriyle ilişkisine yönelik çelişkili sonuçlar olduğu görülmektedir. Bu çalıșma tüketici düşmanlığının ülke imajı ve ürün değerlendirmesi üzerindeki etkilerini kolayda ve beğenmeli mallar açısından anlamayı amaçlamaktadır. Bu amaçla ortaya konan model lisans öğrencileri ile gerçekleştirilen bir anket çalışması ile test edilmiştir. Elde edilen bulgular ülke imajının insan boyutunun (GCA1) satın alma isteğine etkisi; tüketici düşmanlığı ve ülke imajının benzerlik boyutunun (GCA2) ise ürün değerlendirmesine etkisi noktalarında ürün grupları açısından farklılıklar olduğunu göstermektedir. Ayrıca çalışma kapsamında, önceki çalışmaları doğrular nitelikte bir takım sonuçlar da elde edilmiştir. Çalışmada, elde edilen bulgular teorik ve pratik anlamda tartışılmıştır.

Anahtar Kelimeler: Tüketici Düşmanlığı, Ülke İmajı, Ürün Değerlendirmesi, Satın Alma İsteği, Uluslararası Pazarlama.

\section{Özgün Araștırma Makalesi (Original Research Article)}

Geliş/Received: 24.04 .2018

Kabul/Accepted: 03.10 .2018

DOI: http://dx.doi.org/10.17336/igusbd.417316

* Prof. Dr., Anadolu Üniversitesi, İ.İ.B.F., Eskişehir, Türkiye, E-posta: sozturk@anadolu.edu.tr ORCID ID https://orcid.org/0000-0002-0031-7708

** Doç. Dr., Anadolu Üniversitesi, İ.İ.B.F., Eskişehir, Türkiye, E-posta: fzozata@anadolu.edu.tr ORCID ID https://orcid.org/0000-0002-3338-0308

*** Arş. Gör., Karamanoğlu Mehmetbey Üniversitesi, İ.İ.B.F., Karaman, Türkiye, E-posta: ferol@kmu.edu.tr ORCID ID https://orcid.org/0000-0002-0923-380X 


\title{
A Research on the Effect of Consumer Animosity on the Country Image, Product Evaluation and Willingness to Buy Foreign Products
}

\begin{abstract}
Nowadays, consumers in many countries and almost all product groups are faced with foreign product options particularly with the influence of globalization. This situation leads to many researches on consumers' willingness to buy foreign products, consumer animosity and the country image. However, it is seen in the literature that these structures still have contradictory results in relation to each other. This study aims to understand the effects of consumer animosity on the country image and product evaluation in terms of convenience and shopping goods. The model presented for this purpose was tested by a questionnaire study with undergraduate students. As a result, the effect of the human dimension of the country image (GCA1) on willingness to buy and the effects of consumer animosity and similarity dimension of the country image (GCA2) on product evaluation were found to have differences in terms of product groups. In addition, some results confirming previous studies have been obtained in the scope of the study. The findings of the study were discussed in theoretical and practical sense.
\end{abstract}

Keywords: Consumer Animosity, Country Image, Product Evaluation, Willingness to Buy, International Marketing.

\section{GİRIŞ}

Küreselleşme olgusu ve bilişim teknolojilerinde yaşanan gelişmeler neticesinde ülkeler arasındaki fiziki sınırlar ortadan silinmeye yüz tutmuş, uluslararası işletmecilik ve pazarlama faaliyetleri her zamankinden daha yaygın bir hâl almıștır. Yaşanan bu gelişmelere karșın uluslararası ticaretin önündeki bütün engeller ortadan kalkabilmiş değildir. Zira tüm bu gelişmelerin merkezinde yer alan birey, satın alma kararlarında fiziki imkânların ötesinde pek çok değişkeni de göz önünde bulundurabilmektedir. Bu nedenle uluslararası pazarlama literatüründe önemli bir yere sahip olan tüketici düşmanlı̆̆ı, ülke imajı ve ürün değerlendirmesi gibi konuların anlaşılması önem taşımaktadır.

Ülkeler arasındaki ilişkiler incelendiğinde bu ilişkilerin politik, ekonomik ya da geçmişte yaşanmış savaşlardan (Klein vd., 1998, s. 90) kaynaklanan çeşitli sebeplerden ötürü gerilebileceği ve zarara uğrayabileceği görülmektedir. Yaşanan bu tür olumsuzluklar, özellikle tüketicilerin ithal ürün tercihlerinde belirleyici bir faktör olarak öne çıkmaktadır (Ünal, 2017, s. 1). Örneğin 2003 yılında, Irak Savaşı'nın başlaması sonrası Amerikan ürünlerine yönelik dünya çapında bir boykot başlamış, Starbucks, Microsoft ve Coca-Cola gibi küresel markalar dahi bu boykotun hedefleri haline gelmiştir (Cui vd., 2012, s. 494). Keza Avustralyalı ve Yeni Zelandalı tüketicilerin Fransa'nın Pasifik Okyanusundaki nükleer testleri nedeniyle bu ülkeyi boykot etmesi ise diğer bir 
örnektir (Klein vd., 1998, s. 90). Bu örnekler ülkeler arasında ortaya çıkabilecek farklı gerekçelere ve kapsamlara sahip düşmanlıkların tüketici tutum ve niyetinde sebep olabileceği olumsuzlukları ortaya koymaktadır. Nitekim uluslararası pazarlama çabalarına konu olan tüketici davranışları üzerindeki önemi sebebiyle tüketici düşmanlığı, çok sayıda araştırmaya konu olma özelliği taşımaktadır (Klein vd., 1998; Junk vd., 2002; Nijssen ve Douglas, 2004; Ishii, 2009; Cui vd., 2012; Shoham vd., 2016).

Uluslararası pazarlama literatürünün önemli konularından ülke imajının, ürünlerin tüketicilerce kabullenilmesi ve başarıya ulaşmasında etkisi ilk defa Dichter (1962) tarafından ortaya konulmuş, süreç içerisinde bu alanda çok sayıda araştırma gerçekleștirilmiștir (Verlegh ve Steenkamp, 1999; Lala vd., 2009; Roth ve Diamantopoulos, 2009; Dagger ve Raciti, 2011; Maher ve Carter, 2011; Sun ve Paswan, 2011; Kan vd., 2014; Öztürk vd., 2017).

Nagashima (1970) ülke imajını iş adamları ve tüketicilerin belirli bir ülkenin ürünleriyle ilişkilendirdikleri resim, itibar, kalıp yargı olarak ifade etmiştir. Günümüzde ise bu kavram artan önemiyle bir ülkenin ürünlerine yönelik değerlendirme olmanın ötesine geçmiş; yabancı yatırımcıları, turistleri, müşterileri, öğrencileri ve kalifiye işgücünü çekmede etkin bir araca dönüşmeye başlamıştır (Öztürk vd., 2017, s. 81). Ülke imajı, tüketicilerin ürün değerlendirmesinde etnosentrizmle birlikte sıkça ele alınmasına karşın; ürünün kendine has özellikleri, markası, dâhil olduğu ürün grubu gibi çeşitli unsurlar da tüketicilerin ürün değerlendirme sürecine dâhil olabilmektedir. Bu yönüyle ürün değerlendirmesi de araștırmalarda yer verilen diğer bir önemli yapı olarak öne çıkmaktadır.

Yabancı ürünlerin satın alınması sürecinde önemli etkileri olan tüketici düşmanlığı ve ülke imajına yönelik çok sayıda çalışma yapılmış olmasına karşın, literatürde bu yapıların birbirleriyle ilişkisine yönelik çelişkili sonuçlar olduğu görülmektedir. Bir yandan tüketici düşmanlığının karar sürecinin sonunda davranış üzerinde olduğu görüşü savunan araştırmacılar yer alırken, diğer tarafta düşmanlığın bir duygu olarak tüm süreçte etkili olduğu (menșe ülke ve ürün değerlendirmeleri üzerinde etkili olduğu) görüşünü taşıyan çalışmalar da bulunmaktadır. Ortaya çıkan bu bulguların ürün ve ülke bağlantılı faktörlerden kaynaklandığı öngörülmektedir. Dolayısıyla bu çalışma Türk tüketicilerin, Amerikan malı kolayda ve beğenmeli ürünlere yönelik satın alma istekleri ile birlikte, ülke imajı ve ürün değerlendirmelerinin tüketici düşmanlığı ile ilişkisini ortaya koymayı amaçlamaktadır. Bu amaçla öncelikli olarak tüketici düşmanlığı, ülke imajı, ürün değerlendirme ve satın alma isteği değişkenlerine ilişkin literatür taraması gerçekleștirilmiş, elde edilen bilgiler ıșığında ise araștırma modeli ve hipotezleri geliștirilerek bir takım bulgular elde edilmiștir.

\section{LİTERATÜR İNCELEMESİ}

\subsection{Tüketici Düşmanlığı}

Uluslararası pazarlama alanında yapılan pek çok çalıșmada, ülke imajı ve marka isminin tüketicilerin ürün algılamalarını geliştirmek ve rekabet avantajı kazanmak için anahtar yapılar olduğu vurgusu yapılmıştır (Aaker, 1991; Keller, 2003; Chan vd., 2010). Tüketici düşmanlığı kavramı ise, öne sürüldüğü ilk günden itibaren uluslararası 
pazarlama literatüründe yabancı ürün satın alma isteği üzerinde önemli bir diğer belirleyici olarak büyük ilgi toplamıștır (Klein vd., 1998, s. 90; Riefler ve Diamantopoulos, 2007, s. 87). Tüketici düşmanlığı; bir ülkenin ürünlerine yönelik olarak, bu ülkeyle önceden yaşanmış ve bitmiş veya hâlâ sürmekte olan askeri, politik veya ekonomik olaylardan dolayı antipati duyma, hoşlanmama durumu olarak tanımlanmaktadır (Klein vd., 1998, s. 91). Diğer bir tanımlamaya göre ise tüketici düşmanlığı; hoşlanılmayan bir ulus ya da gruptan ürün almaya yönelik güçlü olumsuz duyguları ifade etmektedir (Rose vd., 2009, s. 330). Tüketici düşmanlığı, tüketicilerin belirli bir ülkeye yönelik duygularının bir çeşit yansımasını ifade etmesi sebebiyle, tüketim davranışları üzerinde uzun vadeli etkilere neden olabilmekte ve hatta yıllarca sürebilecek bir tüketici boykotuna sebebiyet verebilme potansiyeli taşımaktadır (Klein vd., 1998; Shimp vd., 2004; Podoshen, 2005).

Tüketici düşmanlığı, yapılan önceki çalışmalarda farklı yoğunluklara sahip çeşitli boyutlardan oluşmakta olan bir yapı olarak ele alınmıştır (Klein vd., 1998; Shin, 2001; Klein, 2002). Nitekim günümüze kadar bu boyutların ortaya konulabilmesi için çok sayıda araştırma gerçekleștirilmiştir. Yaygın kullanılan yapılardan birisi tüketici düşmanlığını; savaş düşmanlığı, ekonomik düşmanlık (Junk vd., 2002; Nijssen ve Douglas, 2004), dinsel düşmanlık ve kişisel düşmanlık şeklinde dört boyutta ele almaktadır (Riefler ve Diamantopoulos, 2007). Ang vd. (2004) tüketici düşmanlığına ilişkin boyutları; "kalıcı veya durumsal" ve "kişisel veya milli" düşmanlık olarak ifade etmektedir. Kalıcı düşmanlık, iki ülke arasındaki zorlu tarihsel ilişkiler sonucu ortaya çıkan ve nesilden nesile aktarılan düşmanlık türüyken durumsal düşmanlık, ülkeler arasındaki mevcut ekonomik ve siyasi olaylardan kaynaklanmakta ve olayların etkisi azaldığında, tüketicilerin söz konusu ülkelere yönelik düşmanca tavırları azalabilmektedir. Kişisel ve milli düşmanlık ayrımı ise, olumsuz hissiyata hedef olan ülkeye yönelik düşmanlık duygusunun mikro veya makro seviyede olmasına bağlı olarak gerçekleşmektedir (Ang vd., 2004, s. 192; Amine, 2008, s. 408). Klein vd. (1998) ise tüketici düşmanlığı algısının savaş düşmanlı̆̆ı, ekonomik düşmanlık ve politik düşmanlık olmak üzere üç boyuttan meydana geldiğini ileri sürmektedir. Kiracı (2017) ise yaptığı literatür taraması içinde yerli (iç) düşmanlık, politik düşmanlık ve bölgesel düşmanlık gibi yeni düşmanlık türlerinin de olabileceğini öne sürmektedir.

\section{2. Ülke İmajı}

Ülke imajı (menșe ülke imajı, orijin ülke değerlendirmesi, menşe ülke etkisi olarak da adlandırılmaktadır); tüketicilerin yabancı ürünleri değerlendirmesine yönelik gerçekleştirilen araştırmalarda kullanılan başlıca değişkenlerdendir (Schooler, 1971, s. 71; Nagashima, 1977, s. 1) ve tüketici davranışları, uluslararası pazarlama ve uluslararası işletmecilik alanlarında bu unsura ilişkin araştırmalar her geçen gün derinleșerek devam etmektedir (Peterson ve Jolibert, 1995, s. 883).

Ülke imajı, hem ülke hem de o ülkede üretilen ürüne dair imajların tümünü kapsamakta ve ülkenin üretim, pazarlama gücü veya zayıflığına dair ön algılara dayanmaktadır (Koubaa, 2008, s. 140). Nagashima (1970, s. 68)'ya göre ülke imajı; temsil edilen ürünler, ulusal karakteristik, ekonomik ve politik temeller, tarih ve 
geleneklere bağlı olarak oluşurken, Shimp (1984, s. 285)'e göre ise bu imaj; kitle iletişim araçlarının yönlendirici etkisi, tüketicilerin kişisel deneyim ve görüşleri ve toplumdaki kanaat liderlerinin tüketiciler üzerindeki etkisi aracılığıyla şekillenmektedir. Buna göre ülke imajı, belirli bir ülkeye ait ürün ve hizmetlerin somutlaştırıldığı bir kavram olmanın ötesinde aynı zamanda ülkenin ekonomik ve politik olgunlaşma derecesi, tarihsel geçmişi ve ilişkileri, kültür ve gelenekleri, teknolojik gelişmişliği ve endüstrileşme düzeyi gibi faktörlerin etkileşimi sonucu oluşan bütünleşik bir yapıdır (Mutlu vd., 2011, s. 54). Bununla birlikte ürün hakkında önceden elde edilen izlenimler, geçmiş satın alma deneyimleri, ürüne yönelik olumlu veya olumsuz önyargılar da ülke imajını etkileyen faktörlerdendir (Cengiz, 2009, s. 157).

Ülke imajı, tüketicilerin menşe ülke algılamalarına göre șekillenmektedir. Verlegh ve Steenkamp (1999, s. 524)'a göre tüketicilerin ülke algılamaları; bilişsel, duygusal ve normatif olmak üzere temel olarak üç boyuttan meydana gelmektedir. Buna göre bilişsel boyut; ürünün kalitesine yönelik ipuçlarını, duygusal boyut; ülke ve o ülkenin insanlarına yönelik sembolik ve duygusal değerleri, normatif boyut ise; bireyin kendi kişisel veya sosyal normları doğrultusunda yerli ürünü tercih etmesi veya düşman olarak algıladığı ülkenin ürünlerini almayı reddetmesi durumlarını içermektedir. Lala vd. (2009)'ne göre ülke imajının boyutları ekonomik koşullar, çatışma, siyasi yapı, mesleki eğitim, çevre, emek ve iş kültüründen oluşurken; Roth ve Diamantopoulos (2009)'a göre boyutlar ekonomik güç, siyasi durum, kültürel yapı, genel yapı, toplum, iş gücü, insan özellikleri ve mesleki eğitim şeklindendir. Parameswaran ve Pisharodi (1994)'ye göre ise ülke imajı; genel ülke özellikleri (GCA), genel ürün özellikleri (GPA) ve spesifik ürün özellikleri (SPA) olmak üzere üç temel boyuta sahip olmalıdır. Ayrıca bu boyutlar da alt boyutlardan oluşmaktadır. Örneğin genel ülke özellikleri (GCA) boyutu, insan özellikleri (GCA1) ve algllanan benzerlikler (GCA2) olmak üzere iki alt boyuta sahiptir. Nitekim ülke imajının boyutlarına ilişkin daha pek çok araştırmanın varlığına karşın bu boyutların neler olduğu noktasında ortak bir karara varılamadığı açık bir şekilde görülmektedir.

\section{3. Ürün Değerlendirme}

Tüketiciler ürünleri değerlendirirken ürünlerin kendine özgü özelliklerinin yanı sıra menşe ülke imajı, tüketicinin etnosentrizm düzeyi gibi unsurlar da değerlendirmelerini etkileyebilmektedir. (Hong ve Wyer, 1990, s. 278). Ürüne değerlendirmesinde önemli olan diğer bir nokta ise, bahsi geçen ürünün belirli bir ürün grubuna ait olması veya küresel bir konuma sahip olmasiyla ilgilidir (Carter, 2009, s. 18). Zira bazı ürün gruplarının belirli ülkelerde üretilmiş olması, o ürün veya markaya yönelik olumlu kalite algısı yaratabilmektedir. Örneğin Fransız şarabı, Hollywood filmleri ve İsviçre'de üretilmiş bir saat gibi (Chan vd., 2010, s. 212). Tüketiciler tarafından küresel konuma sahip markaların değerlendirilmesi ise ürüne yönelik değerlendirmelerden ziyade ülke imajıyla ilgilidir. Bu ürünler, birbirlerinden özellik açısından ufak farklılıklarla ayrılsalar da, küresel markalara yönelik bütüncül değerlendirmenin, o markanın ait olduğu ülkenin imajından farklılaşmadığı görülmektedir (Papadopoulos vd., 2000). Bu bağlamda, ülke imajından bağımsız olarak 
tüketicinin ürün değerlendirmesini anlamaya yönelik araștırmalarda, belirli ürün gruplarından hareket edilmesinin daha uygun olacağı kabul edilmektedir. Bu düşünceden hareket edilerek mevcut çalışmada tüketicilerin ürün değerlendirmesi kolayda ürünler ve beğenmeli ürünler için ayrı ayrı araştırılmıştır.

\subsection{Satın Alma İsteği}

Ürüne yönelik inanç, tutum ve davranışlar pek çok tüketici davranışı modelinin ana temasını oluşturmaktadır. Tutum oluşumu ile ilgili olarak, Fishbein ve Ajzen (1975)'in çok nitelikli tutum modeli; bireyin bir nesneye yönelik toplam tutumunun, bu nesneye yönelik inançların sayı ve gücüyle ilintili olduğunu ifade etmektedir. Bu noktada bireyin toplam tutumundaki değişim; ürüne yönelik inancın manipüle edilmesi, yeni inanç oluşturulması veya varolan inancın değiştirilmesiyle mümkün olabilmektedir. Kimi çalışmalara göre davranışsal niyet, tüketicinin bir ürünü satın alması gibi spesifik eğilimlerini yansitmakta iken (Baker ve Churchill, 1977; Kilbourne 1986; Okechuku ve Wang 1988), satın alma niyetini belirli ürünleri satın almaya yönelik davranışsal eğilim olarak değerlendiren yazarlar da bulunmaktadır (Hui ve Zhou, 2002). Diğer bazı araştırmacılar ise satın alma niyetini, tüketicinin ürünü zaman içerisindeki satın alma isteği olarak ifade etmektedir (Dodds vd., 1991; Ulgado ve Lee, 1998).

\section{ARAŞTIRMA MODELİ VE HIPOTEZLERIN GELISSTTIRILMESI}

Literatürdeki mevcut çalışmalarda tüketici düşmanlığının, ülke imajı ve ürün değerlendirmeyle olan etkileşimi noktasında görüş ayrılıkları hâkimdir. Klein vd. (1998)'ne göre tüketici, düşmanlık hissettiği ülkenin ürünlerine yönelik olumlu değerlendirmelerde bulunabilir, fakat tüketici yine de bu ülkenin ürünlerini almaktan kaçınır. Baillargeon (2003)'e göre tüketici ürün değerlendirmesinde hem bilișsel hem de duygusal unsurlardan etkilenmektedir. $\mathrm{Bu}$ noktada tüketiciler, etkiyi bilişten ayıramadıkları için tamamen objektif değerlendirme yapamamakta, böylelikle ürün değerlendirmeleri de olumsuz yönde gerçekleşmektedir. Bununla birlikte literatürde, tüketici düşmanlığının ürün değerlendirmesi üzerinde olumsuz yönde etkisi olduğunu ortaya koyan başka çalışmalar da mevcuttur (Zajonc, 1980; Berkowitz vd., 2000; Leong vd., 2008; Ishii, 2009; Huang vd., 2010). Nitekim $\mathrm{H}_{1}$ hipotezi aşağıda belirtilmiștir:

- $\quad H_{1}$ : Tüketici düşmanlı̆̆ı, yabancı ürünlerin değerlendirilmesi üzerinde olumsuz bir etkiye sahiptir.

Geçmiş çalışmalar tüketici düşmanlığının, etnosentrizmden farklı olarak belirli bir ülkeye veya firmaya yönelik olarak geliştiğini ortaya koymaktadır (Klein vd., 1998; Klein, 2002). Bu nedenle tüketicinin, düşmanlık hissettiği ülkenin imajının bu durumdan etkilenmesi olası bir sonuçtur. Zaten çoğu ülke imajı araştırmasının genel amacı, zamanın bir noktasında ülkenin veya ülkelerin görüntüleri hakkında bilgi vermek ve görüntü bileşenleri veya boyutlar arasındaki ilişkilerin modelini sağlamaktır. Bununla birlikte, ülke imajları bazen yavaş, bazense çok hızlı bir şekilde değișebilir. Bu değişim çeşitli sebeplerden kaynaklanabilmekle birlikte düşmanlık yaratan olaylara tepki olarak 
da gerçekleșebilir (Heslop vd., 2008, s. 355). Bu düşünceden hareketle kurgulanan $\mathrm{H}_{2}$ hipotezi aşağıdaki gibidir:

- $\quad H_{z a}$ : Tüketici düşmanlığı, ülke imajı (GCA1-insan özellikleri) üzerinde olumsuz bir etkiye sahiptir.

- $H_{2 b}$ : Tüketici düşmanlığı, ülke imajı (GCA2-algılanan benzerlikler) üzerinde olumsuz bir etkiye sahiptir.

Klein vd. (1998) ve Klein (2002)'a göre; yabancı ürün satın alma isteğine yönelik çok sayıdaki araştırmadan farklı olarak tüketici düşmanlığı, bireyin satın alma isteğini, ürünü değerlendirmesinden bağımsız olarak doğrudan ve olumsuz şekilde etkilemektedir. $\mathrm{Bu}$ bağlamda düşmanlık taşıyan tüketiciler; ekonomik, politik veya askeri sebeplerden ötürü antipati duydukları ülke veya firmanın ürününe yönelik bir değerlendirmede bulunmaksızın bu ürünleri direkt olarak satın almaktan kaçınmaktadır. Ayrıca tüketici düşmanlığının satın alma isteğini olumsuz yönde etkilediğini ortaya koyan başka çalışmalar da mevcuttur (Nijssen ve Douglas, 2004; Huang vd., 2010; Tian ve Pasadeos, 2012; Shoham vd., 2016). Bu bilgiler doğrultusunda $\mathrm{H}_{3}$ hipotezi geliştirilmiştir:

- $\quad H_{3}$ : Tüketici düşmanlı̆̆ı, yabancı ürün satın alma isteği üzerinde doğrudan ve olumsuz bir etkiye sahiptir.

Ülke imajına yönelik genel yaklaşım, ülke imajının satın alma isteğini ürün değerlendirmesi ve ürüne yönelik tutum değișkenleri vasıtasıyla etkilediği yönündedir. Nitekim Peterson ve Jolibert (1995)'in çalışmasına göre ülke imajı, ürün değerlendirmesi üzerinde etkilidir. Dahası ülke imajı, kalite/dayanıklılık gibi satın alma isteği üzerinde etkili olan unsurlar açısından da bir öngörü unsurudur (Pharr, 2005). Çoğu araştırmacıya göre ülke imajı, satın alma isteğini diğer değişkenler vasıtasıyla etkilemektedir (Hui ve Zhou, 2002; Parameswaran ve Pisharodi, 2002; Cervino vd., 2005). Bu bilgiler ışığında $\mathrm{H}_{4}$ hipotezi şu şekilde geliştirilmiştir:

- $\quad H_{4 a}$ : Ülke imajı (GCA1), yabancı ürünlerin değerlendirilmesi üzerinde olumlu bir etkiye sahiptir.

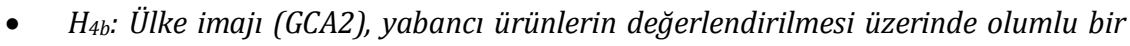
etkiye sahiptir.

Ülke imajıyla satın alma isteği arasındaki ilişki çeşitli çalışmalarda farklı bakış açılarına göre incelenmiştir. Nitekim kimi araştırmalara göre ülke imajı satın alma isteğini diğer değişkenler aracılığıyla etkilemektedir (Hui ve Zhou, 2002; Parameswaran ve Pisharodi, 2002; Cervino vd., 2005). Diğer yandan ülke imajının satın alma isteğine doğrudan etkisi ortaya koyan birçok araştırma bulgusu da mevcuttur (Maher ve Carter, 2011; Dagger ve Raciti, 2011; Sun ve Paswan, 2011; Kan vd., 2014). Ülke imajıyla satın alma isteği arasındaki doğrudan ilișkiyi gösteren bu bulgulardan hareket edilerek $\mathrm{H}_{5}$ hipotezi geliştirilmiştir:

- H5a: Ülke imajı (GCA1), yabancı ürün satın alma isteği üzerinde olumlu bir etkiye sahiptir.

- $\quad H_{5 b}$ : Ülke imajı (GCA2), yabancı ürün satın alma isteği üzerinde olumlu bir etkiye sahiptir.

Tüketicilerin menșe ülke etkisine bağlı olarak ürüne yönelik geliștirdikleri pozitif/negatif algıların, yabancı ürün satın alma isteğini etkilemesi beklenmektedir 
(Balabanis vd., 2001). Bu alanda yapılan geçmiş çalışmalar, ürün değerlendirmesinin satın alma isteğini doğrudan etkilediğini ortaya koymuştur (Chinen vd., 2000; Hui ve Zhou, 2002; Orbaiz ve Papadopoulos, 2003). Buna göre $\mathrm{H}_{6}$ hipotezi aşağıdaki gibidir:

- $\quad H_{6}$ : Türk tüketicilerin yabancı ürünleri değerlendirmesi, bu yabancı ürünleri satın alma isteği üzerinde olumlu bir etkiye sahiptir.

$\mathrm{Bu}$ bilgilerden hareketle aşağıda araștırma modeli ve hipotezler sunulmaktadır:

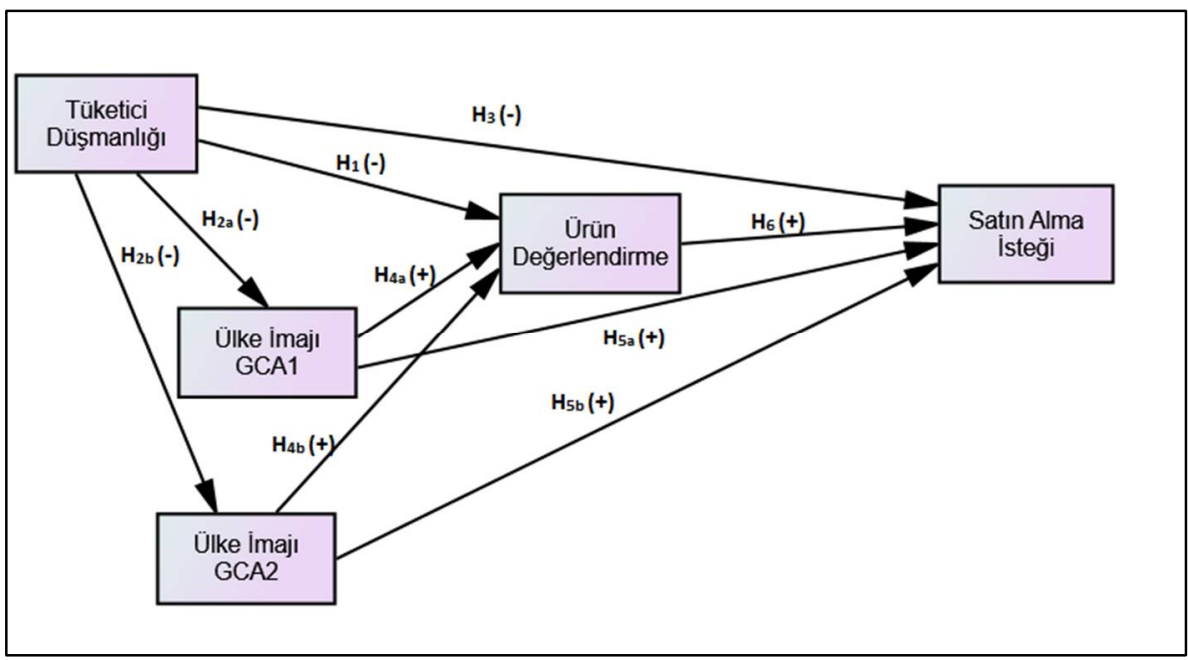

Şekil 1: Araștırma Modeli ve Hipotezler

\section{TÜKETICI DÜŞMANLIĞININ ÜLKE İMAJI, ÜRÜN DEĞERLENDİRME VE YABANCI ÜRÜN SATIN ALMA İSTEĞINE ETKISII ÜZERINNE BİR ARAŞTIRMA \\ 4.1. Araştırmanın Amacı ve Önemi}

Çalışmanın amacı, uluslararası pazarlama faaliyetleri açısından büyük önem taşıyan tüketici düşmanlığı, ülke imajı ve ürün değerlendirmesi değişkenlerinin gerek birbirleri üzerindeki gerekse satın alma isteği üzerindeki etkilerinin ortaya konulmasıdır. Bu nedenle tüketici düșmanlığı, ülke imajı, ürün değerlendirmesi ve satın alma isteği arasındaki ilişkiler tespit edilmeye çalıșılmıştır.

Ekonomik ve politik güç olma noktalarında dünyanın önde gelen ülkelerinden birisi olan Amerika Birleşik Devletleri (ABD); küresel çapta yürüttüğü faaliyetler hasebiyle, bilhassa Ortadoğu'da, kimi noktalarda Türkiye ile müttefik olurken, kimi noktalarda anlaşmazlıklar yaşayabilmekte (Molla, 2009); bu durum her iki ülkenin de vatandaşları üzerinde tüketim tercihleri noktalarında farklı sonuçlar doğurabilmektedir. ABD'nin Irak'ı işgal ettiği dönemde dünyanın pek çok yerinde olduğu gibi Türk tüketicilerin de ABD'ye yönelik ürünleri boykot etmesi bu duruma örnek gösterilebilir (Hürriyet, 2003). Bu politik ilişkilerin haricinde ABD, 2016 yılı verilerine göre Türkiye'nin en çok ihracat yaptığı 5. ülke iken, yine Türkiye'nin en çok ithalat yaptığı 4. 
ülke olma özelliğine de sahiptir (TÜíK, 2018). Dolayısıyla günümüzde, bahsi geçen ülkeler gerek izledikleri uluslararası politikalar gerekse geliştirdikleri ekonomik ilişkiler sebebiyle sıkı bir etkileşim içerisinde olduğundan bu çalışmanın da öznesi olarak belirlenmişlerdir.

Literatürde tüketici düşmanlığı, ülke imajı, ürün değerlendirmesi ve satın alma isteği değişkenlerini bir arada ya da ayrı ayrı olarak ele alan, Türkiye karşılaştırmalı çeşitli çalışmalar mevcuttur. Bu çalışmalardan bazıları; Fransa (Hacıoğlu vd., 2013), İsrail (Fettahlığlu ve Sünbül, 2015), Çek Cumhuriyeti (Balabanis vd., 2001; Balabanis vd., 2002), Suriye (Mutlu vd., 2011) ve Amerika (Akdoğan vd., 2012; Özer ve Dovganiuc, 2013; Eren, 2013; Kiracı ve Kayabaşı, 2018) şeklindedir. Bunlar içinde menşe ülke olarak ABD’nin seçildiği çalışmalara biraz daha yakından bakacak olursak; Akdoğan vd. (2012)'nin tüketici düșmanlığı ve etnosentrizmin Türk tüketicilerin ABD ürünlerini tekrar satın alma niyeti üzerindeki etkisini ve tüketici sadakatinin aracı rolünü inceledikleri; Özer ve Dovganiuc (2013)'un Türk tüketicilerin Türk ve ABD ürünlerine yönelik genel ürün değerlendirmesi, spesifik ürün imajı, etnosentrik eğilimler ve gösteriş amaçlı tüketiminin, gösteriş amaçlı ürünlerin satın alınması üzerindeki doğrudan ve düzenleyici etkilerini inceledikleri; Eren (2013)'in genç Türk tüketicilerinin etnosentrizm ve düşmanlığın ABD'ye, tüketicilerin ürün satın alma konusundaki kararlarına ve Amerikan ürünlerini satın alma konusundaki istekliliğine etkisini inceledikleri ve Kiracı ve Kayabașı (2018)'nın Türk tüketicilerin Amerikan mal ve hizmetlerine yönelik düşmanlıklarının (altı farklı düşmanlık türü bağlamında) ve etnosentrik eğilimlerinin yabancı ürün satın almama niyeti üzerindeki etkilerini inceledikleri görülmektedir. Dolayısıyla bu çalışmanın özellikle kolayda ve beğenmeli olmak üzere iki farklı ürün grubu açısından gerçekleştirilmesi, daha önce ele alınmamış olması itibariyle özgünlüğünü arttırmaktadır. Ayrıca geliştirilen araştırma modeli ışığında değişkenler arasında sınanan ilişkilerin literatüre katkı sağlayacağı düşünülmektedir. Son olarak ABD ile politik ve ekonomik ilişkilerin çok sık değişkenlik gösterdiği günümüz koşullarında çalışmadan elde edilecek sonuç ve çıarımların, uygulayıcılar açısından yol gösterici bir nitelik taşıyacağına inanılmaktadır.

\subsection{Evren, Örneklem ve Yöntem}

Çalışma evreni olarak Karamanoğlu Mehmetbey Üniversitesi (KMU) İktisadi ve İdari Bilimler Fakültesi (İ̈BF) öğrencileri belirlenmiştir. Örneklem ise, söz konusu fakülte öğrencileri arasından tesadüfî olmayan örnekleme yöntemlerinden kolayda örneklem tekniği ile seçilmiştir. Öğrencilerle yüzyüze görüşmek suretiyle gerçekleştirilen anket çalışması yardımıyla elde edilen veriler, SPSS 21 ve Amos 23 programları yardımıyla analiz edilmiştir. Araştırma kapsamında öncelikli olarak 23.11.2017 ve 24.11.2017 tarihleri arasında 30 öğrenci ile bir test gerçekleştirilmiş ve bu test yardımıyla öğrencilerin Amerika ile yüksek derecede ilișkilendirdikleri ürünler tespit edilmiştir. Söz konusu test kapsamında öğrencilere önce kolayda ürünler olan; kahve, donat, hamburger, gazlı içecek ve kahvaltılık gevrek arasından ABD ile en çok bağlantı kurdukları bir ürünü seçmeleri istenmiştir. Sonrasında ise yine aynı öğrencilere beğenmeli ürünler olan; spor kıyafet, fotoğraf makinesi, cep telefonu, müzik çalar (Mp3 
Player), tablet ve video oyun konsolu arasından ABD ile en çok bağlantı kurdukları bir ürünü seçmeleri istenmiştir. Bu testten elde edilen sonuçlar doğrultusunda araştırmada kolayda ürün olarak "gazlı içecek", beğenmeli ürün olarak ise "cep telefonu" kullanılmıştır. Yapısal Eşitlik Modeli literatüründe, kesin standartlar olmamakla birlikte, örneklem sayısı ile gözlenen değişken arasında 10:1'lik bir oranın istenen sonuçlara ulaşmak açısından yeterli olacağı görüşü hakimdir (Hair vd., 2013). Buradan hareketle 18.12.2017-29.12.2017 tarihleri arasında ise 525 öğrenciye anket uygulanmış, toplam 502 adet kullanılabilir anket elde edilmiş ve analizler bu anketlerden elde edilen verilerle gerçekleștirilmiştir.

\section{3. Ölçekler}

Araştırma değişkenlerinin ölçümü noktasında; tüketici düşmanlığı, ülke imajı, ürün değerlendirme ve satın alma isteğine ilişkin geçerliliği kabul edilmiş, literatürde yaygın olarak kullanılan ölçeklerden faydalanılmıştır. Tüketici düşmanlığı değişkeni, genel ve ekonomik düşmanlığı ölçen Klein vd. (1998) ve Klein (2002)'den elde edilen 8 ifade yardımıyla ölçülmüştür. Ülke imajı değişkeni Parameswaran ve Pisharodi (1994)'den elde edilen 8 ifade yardımıyla ölçülmüştür. Bu değişken GCA1 (insan özellikleri, 5 ifade) ve GCA2 (algılanan benzerlikler, 3 ifade) olmak üzere 2 boyutlu (Pisharodi ve Parameswaran, 1992; Pereira vd., 2005) olarak ele alınmıştır. Ürün değerlendirmeye yönelik ölçek "Darling ve Arnold (1988)", “Darling ve Wood (1990)", “Wood ve Darling (1993)"'ten uyarlanan 6 ifadeden oluşurken; satın alma isteğini ölçmeye yönelik ölçek yine "Darling ve Arnold (1988)", "Darling ve Wood (1990)" ve “Wood ve Darling (1993)"'ten uyarlanan 5 ifadeden oluşmaktadır. Anketteki tüm ifadeler 5'li Likert tipi ölçek kullanılarak yöneltilmiştir. Ölçeklerde yer alan ifadelerin tamamı EK-1'de verilmiştir.

\subsection{Verilerin Analizi ve Bulgular}

Öncelikli olarak araştırmaya katılanlara ilişkin demografik bilgiler Tablo 1 yardımıyla verilmiştir. Buna göre çalışmaya katılanların \%60'ını kadın öğrenciler oluşurken yaklaşık \%40'ı ise erkeklerden oluşturmaktadır. Ayrıca katılımcıların çoğunluğunun $(\% 29,1) 21$ yaşında olduğu ve aylık barınma dışı harcanabilir ortalama tutarların 251-500 TL arasında olduğu görülmektedir. Katılımcılar öğrenim gördükleri bölümler açısından değerlendirildiğinde ise büyük çoğunluğun sırasıyla İşletme ve Siyaset Bilimi ve Kamu Yönetimi bölümlerinden oluştuğu görülmektedir.

Tablo 1: Katılımcllara İlişkin Demografik Bilgiler ( $\mathrm{n}=502)$

\begin{tabular}{|l|l|l|l|l|l|}
\hline & Sayı & Yüzde & & Sayı & Yüzde \\
\hline Cinsiyet & & & Aylı Gelir* & & \\
\hline Kadın & 302 & 60,2 & 250 TL ve altı & 104 & 20,7 \\
\hline Erkek & 200 & 39,8 & 251-500 TL arası & 238 & 47,4 \\
\hline Yaş & & & 501-750 TL arası & 71 & 14,1 \\
\hline 18 & 8 & 1,6 & 751-1000 TL arası & 50 & 10,0 \\
\hline
\end{tabular}




\begin{tabular}{|l|l|l|l|l|l|}
\hline & Sayı & Yüzde & & Sayı & Yüzde \\
\hline 19 & 54 & 10,8 & $1001-1500$ TL arası & 23 & 4,6 \\
\hline 20 & 105 & 20,9 & 1501 TL ve üzeri & 16 & 3,2 \\
\hline 21 & 146 & 29,1 & Bölüm & & \\
\hline 22 & 93 & 18,5 & İşletme & 227 & 45,2 \\
\hline 23 & 71 & 14,1 & İktisat & 58 & 11,6 \\
\hline 24 & 15 & 3,0 & Siy. Bil. ve Kamu Yön. & 217 & 43,2 \\
\hline 25 ve üzeri & 10 & 2,0 & & & \multicolumn{2}{|c|}{} \\
\hline
\end{tabular}

*Aylık gelir bilgisi, barınma dışı aylık harcanabilir ortalama tutarı ifade etmektedir.

Sonrasında kolayda (gazlı içecek) ve beğenmeli (cep telefonu) ürün kategorilerinin ölçüm modeli için doğrulayıcı faktör analizi yapılmıștır. Kolayda ürüne ilişkin veri setine ait doğrulayıcı faktör analizi uyum iyiliği değerleri kabul sinırlarındadır ( $\chi 2 / d f=2,109 ; \mathrm{GFI}=, 911 ; \mathrm{CFI}=, 946$; NFI=,902; IFI=,946; RMSEA=,047). Ayrıca beğenmeli ürüne ilişkin veri setine ait doğrulayıcı faktör analizi uyum iyiliği değerleri de $(\chi 2 / \mathrm{df}=2,113 ; \mathrm{GFI}=, 909 ; \mathrm{CFI}=, 944 ; \mathrm{NFI}=, 900 ; \mathrm{IFI}=, 945 ; \mathrm{RMSEA}=, 047) \mathrm{kabul}$ sınırlarında bulunmuştur (Browne ve Cudeck, 1992; Hair vd., 2013).

Kolayda ürüne ait modelde yer alan yapılara ilişkin güvenilirlik, ortalama ve AVE (açıklanan varyans) değerleri Tablo 2 yardımıyla belirtilmiștir. Buna göre yapı güvenilirliği değerine bakıldığında araştırma modelinde yer alan yapıların tamamının oldukça yüksek güvenilirlik $(>0,80)$ değerlerine sahip oldukları görülmektedir (Özdamar, 2004; Hair vd., 2013). Ölçeklere ilişkin ortalama değerler büyükten küçüğe sırasıyla tüketici düşmanlığı, ülke imajı (GCA1), satın alma isteği, ürün değerlendirmesi ve ülke imajı (GCA2) şeklindedir. Yapının ayrıștırıcı geçerlilik değerini ifade eden AVE değerlerine bakıldığında ise kolayda ürüne ilișkin ölçeklere ait bu değerlerin tamamının, kabul sınırı olarak ifade edilen (,50)'ye (Forner ve Larcker, 1981; Hair vd., 2013) eşit ya da daha büyük olduğu görülmektedir.

Tablo 2: Kolayda Ürüne Ait Katsayı, Güvenilirlik ve AVE Değerleri

\begin{tabular}{|l|l|l|l|l|}
\hline Yapı & Ortalama & SD & Güvenilirlik $^{\mathbf{1}}$ & AVE $^{\mathbf{2}}$ \\
\hline 1. Tüketici Düșmanlığı & 3,96 &, 76 &, 88 &, 50 \\
\hline 2. Ülke İmajı (GCA1) & 3,65 &, 80 &, 89 &, 63 \\
\hline 3. Ülke İmajı (GCA2) & 2,11 &, 76 &, 81 &, 60 \\
\hline 4. Ürün Değerlendirmesi & 2,53 &, 83 &, 90 &, 60 \\
\hline 5. Satın Alma İsteği & 2,85 &, 95 &, 90 &, 66 \\
\hline
\end{tabular}

Tablo 3'te verilen kolayda ürünlere ilişkin ifadelere yönelik korelasyon analizi sonuçlarına göre; ifadeler arasındaki ilişkilerin düşük değerlere sahip olduğu görülmektedir. Literatüre göre değişkenler arasındaki korelasyon katsayısının 0,85-0,90 arasında olmadığı analizlerde, zayıf ilişkiler çoklu doğrusallık problemine sebep olmamaktadır (Field, 2009; Allen ve Bennett, 2010; Lada vd., 2014). Bu bilgiden

\footnotetext{
1 Yapı güvenilirliği hesaplamalarında kullanılan formül $=\frac{\left(\sum \lambda\right)^{2}}{\left(\sum \lambda\right)^{2}+\left(\sum \varepsilon\right)}$ (Hair vd., 2013, s. 619).

${ }^{2}$ AVE değerinin hesaplanmasında kullanılan formül $=\frac{\sum \lambda^{2}}{n}$ (Hair vd., 2013, s. 619).
} 
Sevgi Ayșe Öztürk, Fatma Zeynep Özata, Fuat Erol, “Tüketici Düşmanlığının Ülke İmajı, Ürün Değerlendirme ve Yabancı Ürün Satın Alma İsteğine Etkisi Üzerine Bir Araştırma”, İstanbul Gelişim Üniversitesi Sosyal Bilimler Dergisi, 6 (1), Nisan 2019, ss. 76-101

hareketle değişkenler arasında çoklu doğrusallık probleminin olmadığını söylemek mümkündür.

Tablo 3: Kolayda Ürüne Ait Korelasyon Analizi

\begin{tabular}{|c|c|c|c|c|c|c|}
\hline & & $\begin{array}{l}\text { Tüketici } \\
\text { Düşm. }\end{array}$ & $\begin{array}{l}\text { Ülke } \\
\text { İmajı } \\
\text { (GCA1) }\end{array}$ & $\begin{array}{l}\text { Ülke } \\
\text { İmajı } \\
\text { (GCA2) }\end{array}$ & $\begin{array}{l}\text { Ürün } \\
\text { Değer. }\end{array}$ & $\begin{array}{l}\text { Satın Alma } \\
\text { İsteği }\end{array}$ \\
\hline $\begin{array}{l}\text { Tüketici } \\
\text { Düşmanlığı }\end{array}$ & $\begin{array}{l}\text { Pearson Correlation } \\
\text { Sig. (2-tailed) } \\
\mathrm{N} \\
\end{array}$ & $\begin{array}{l}1 \\
- \\
502 \\
\end{array}$ & $\begin{array}{l}-, 012 \\
, 793 \\
502 \\
\end{array}$ & $\begin{array}{l}-, 196^{* *} \\
, 000 \\
502 \\
\end{array}$ & $\begin{array}{l}-238^{* *} \\
, 000 \\
502 \\
\end{array}$ & $\begin{array}{l}-, 324^{* *} \\
, 000 \\
502 \\
\end{array}$ \\
\hline $\begin{array}{l}\text { Ülke İmajı } \\
\text { (GCA1) }\end{array}$ & $\begin{array}{l}\text { Pearson Correlation } \\
\text { Sig. (2-tailed) } \\
\text { N }\end{array}$ & $\begin{array}{l}-012 \\
, 793 \\
502 \\
\end{array}$ & $\begin{array}{l}1 \\
- \\
502\end{array}$ & $\begin{array}{l}, 040 \\
, 376 \\
502\end{array}$ & $\begin{array}{l}, 234^{* *} \\
000 \\
502\end{array}$ & $\begin{array}{l}, 130^{* *} \\
004 \\
502\end{array}$ \\
\hline $\begin{array}{l}\text { Ülke İmajı } \\
\text { (GCA2) }\end{array}$ & $\begin{array}{l}\text { Pearson Correlation } \\
\text { Sig. (2-tailed) } \\
\text { N }\end{array}$ & $\begin{array}{l}-, 196^{* *} \\
, 000 \\
502\end{array}$ & $\begin{array}{l}, 040 \\
, 376 \\
502 \\
\end{array}$ & $\begin{array}{l}1 \\
- \\
502 \\
\end{array}$ & $\begin{array}{l}154^{* *} \\
, 001 \\
502 \\
\end{array}$ & $\begin{array}{l}, 029 \\
, 522 \\
502 \\
\end{array}$ \\
\hline $\begin{array}{l}\text { Ürün } \\
\text { Değerlen- } \\
\text { dirmesi }\end{array}$ & $\begin{array}{l}\text { Pearson Correlation } \\
\text { Sig. (2-tailed) } \\
\text { N }\end{array}$ & $\begin{array}{l}-238^{* *} \\
, 000 \\
502\end{array}$ & $\begin{array}{l}, 234^{* *} \\
, 000 \\
502\end{array}$ & $\begin{array}{l}154^{* *} \\
, 001 \\
502\end{array}$ & $\begin{array}{l}1 \\
- \\
502\end{array}$ & $\begin{array}{l}, 281^{* *} \\
, 000 \\
502\end{array}$ \\
\hline $\begin{array}{l}\text { Satın Alma } \\
\text { İsteği }\end{array}$ & $\begin{array}{l}\text { Pearson Correlation } \\
\text { Sig. (2-tailed) } \\
\text { N }\end{array}$ & $\begin{array}{l}-, 324^{* *} \\
, 000 \\
502\end{array}$ & $\begin{array}{l}130^{* *} \\
, 004 \\
502\end{array}$ & $\begin{array}{l}, 029 \\
522 \\
502\end{array}$ & $\begin{array}{l}, 281^{* *} \\
000 \\
502\end{array}$ & $\begin{array}{l}1 \\
- \\
502\end{array}$ \\
\hline
\end{tabular}

$* * \mathrm{p}<0,01$

Tablo 4 yardımıyla beğenmeli ürüne ilişkin yapıya ait güvenilirlik, ortalama ve AVE değerleri verilmiştir. Öncelikli olarak yapılar güvenilirlik açısından incelendiğinde, yapıların tamamının yüksek derecede $(>0,80)$ güvenilir olduğu görülmektedir (Özdamar, 2004; Hair vd., 2013). Ölçeklere ortalamaları açısından bakıldığında büyükten küçüğe sırasıyla tüketici düşmanlığı, ülke imajı (GCA1), ürün değerlendirmesi, satın alma isteği ve ülke imajı (GCA2) șeklinde bir sıralamanın oluştuğu görülmektedir. Ölçeklere ait ayrıştırıcı geçerlilik değerini ifade eden AVE değerinin ise bütün ölçeklerde, kabul sınırı olarak ifade edilen (,50)'ye (Forner ve Larcker, 1981; Hair vd., 2013) eșit veya daha büyük olduğu görülmektedir.

Tablo 4: Beğenmeli Ürüne Ait Katsayı, Güvenilirlik ve AVE Değerleri

\begin{tabular}{|l|l|c|l|l|}
\hline Yapı & Ortalama & SD & Güvenilirlik & AVE \\
\hline 1. Tüketici Düşmanlığı & 3,96 &, 76 &, 88 &, 50 \\
\hline 2. Ülke İmajı (GCA1) & 3,65 &, 80 &, 89 &, 63 \\
\hline 3. Ülke İmajı (GCA2) & 2,11 &, 76 &, 81 &, 60 \\
\hline 4. Ürün Değerlendirmesi & 3,33 &, 81 &, 90 &, 61 \\
\hline 5. Satın Alma İsteği & 3,03 &, 93 &, 91 &, 67 \\
\hline
\end{tabular}

Tablo 5'te verilen, beğenmeli ürüne ait yapının korelasyon analizi sonuçlarına göre, modelde yer alan değișkenler arasındaki en yüksek korelasyonun tüketici düşmanlığı ile satın alma isteği arasında olduğu ( $r=-, 415, \mathrm{p}<0,00)$ belirlenmiștir. En düşük ilişki düzeyi ise tüketici düşmanlığı ile ülke imajı (GCA2) arasındadır (r= -,196, $\mathrm{p}<0,00$ ). Ayrıca beğenmeli ürüne ilişkin değişkenler arasında yüksek korelasyon katsayılarının olmaması nedeniyle bu modelde de değişkenler arasında çoklu 
Sevgi Ayșe Öztürk, Fatma Zeynep Özata, Fuat Erol, “Tüketici Düşmanlığının Ülke İmajı, Ürün Değerlendirme ve Yabancı Ürün Satın Alma İsteğine Etkisi Üzerine Bir Araştırma”, İstanbul Gelişim Üniversitesi Sosyal Bilimler Dergisi, 6 (1), Nisan 2019, ss. 76-101

doğrusallık probleminin olmadığı söylenebilir (Field, 2009; Allen ve Bennett, 2010; Lada vd., 2014).

Tablo 5: Beğenmeli Ürüne Ait Korelasyon Analizi

\begin{tabular}{|l|l|l|l|l|l|l|}
\hline & & $\begin{array}{l}\text { Tüketici } \\
\text { Düşm. }\end{array}$ & $\begin{array}{l}\text { Ülke } \\
\text { İmajı } \\
\text { (GCA1) }\end{array}$ & $\begin{array}{l}\text { Ülke } \\
\text { İmaji } \\
\text { (GCA2) }\end{array}$ & $\begin{array}{l}\text { Ürün } \\
\text { Değer. }\end{array}$ & $\begin{array}{l}\text { Satın } \\
\text { Alma } \\
\text { İsteği }\end{array}$ \\
\hline \multirow{2}{*}{ Tüketici } & Pearson Correlation & 1 &,- 012 &,$- 196^{* *}$ &,- 061 &,$- 415^{* *}$ \\
Düşmanlı̆ı & Sig. (2-tailed) & - &, 793 &, 000 &, 171 &, 000 \\
& $\mathrm{~N}$ & 502 & 502 & 502 & 502 & 502 \\
\hline \multirow{2}{*}{$\begin{array}{l}\text { Ulke İmajı } \\
\text { (GCA1) }\end{array}$} & Pearson Correlation &,- 012 & 1 &, 040 &, $402^{* *}$ &, 086 \\
& Sig. (2-tailed) &, 793 & - &, 376 &, 000 &, 054 \\
& $\mathrm{~N}$ & 502 & 502 & 502 & 502 & 502 \\
\hline \multirow{2}{*}{ Ülke İmajı } & Pearson Correlation &,$- 196^{* *}$ &, 040 & 1 &,- 043 &, 023 \\
(GCA2) & Sig. (2-tailed) &, 000 &, 376 & - &, 335 &, 610 \\
& $\mathrm{~N}$ & 502 & 502 & 502 & 502 & 502 \\
\hline \multirow{2}{*}{ Ürün } & Pearson Correlation &,- 061 &, $402^{* *}$ &,- 043 & 1 &, $267^{* *}$ \\
Değerlendirmesi & Sig. (2-tailed) &, 171 &, 000 &, 335 & - &, 000 \\
& $\mathrm{~N}$ & 502 & 502 & 502 & 502 & 502 \\
\hline \multirow{2}{*}{ Satın Alma İsteği } & Pearson Correlation &,$- 415^{* *}$ &, 086 &, 023 &, $267^{* *}$ & 1 \\
& Sig. (2-tailed) &, 000 &, 054 &, 610 &, 000 & - \\
& $\mathrm{N}$ & 502 & 502 & 502 & 502 & 502 \\
\hline
\end{tabular}

${ }^{* *} \mathrm{p}<0,01$

Geçerlilik ve güvenilirlik analizleri sonrasında değişkenler arası ilişkilerin test edilmesi için yapısal eşitlik modellemesi kullanılmıștır. Araştırmanın örneklem hacmi yapısal eşitlik modellemesi için gerekli olan minimum değer aralığının (n=100-150) üzerindedir (Tinsley ve Tinsley, 1987; Ding vd., 1995). Yapısal eşitlik modellemesine ilişkin analiz sonuçları ile hipotezlerin kabul ve red durumlarının özet hali Tablo 6'da verilmiștir. Tablonun alt kısmında her iki modele ilișkin uyum iyiliği değerleri verilmiştir. Buradan da görülebileceği üzere, uyum iyiliği değerleri her iki model için de kabul edilebilir sınırların üstündedir.

Tablo 6: Hipotezlerin Kabul/Red Durumu

\begin{tabular}{|c|c|c|c|c|c|c|}
\hline & \multicolumn{3}{|c|}{ Kolayda Ürn } & \multicolumn{3}{|c|}{ Beğenmeli Ürün } \\
\hline & SEYK & $P$ & Hipotez & SEYK & $\mathrm{P}$ & Hipotez \\
\hline $\begin{array}{l}\text { Satın Alma İsteği }= \\
\text { + Ürün Değerlendirmesi }\left(\mathrm{H}_{6}\right) \\
\text { - Düşmanlık }\left(\mathrm{H}_{3}\right) \\
\text { + GCA1 }\left(\mathrm{H}_{5 \mathrm{a}}\right) \\
\text { + GCA2 }\left(\mathrm{H}_{5 \mathrm{~b}}\right)\end{array}$ & $\begin{array}{l}\text {,263 } \\
-, 312 \\
, 116 \\
-151\end{array}$ & $\begin{array}{l}* * * \\
* * * \\
013^{*} \\
004\end{array}$ & $\begin{array}{l}\text { Kabul } \\
\text { Kabul } \\
\text { Kabul } \\
\text { Red }\end{array}$ & $\begin{array}{l}, 287 \\
-, 429 \\
-, 039 \\
-, 042\end{array}$ & $\begin{array}{l}* * * \\
* * * \\
448 \\
405\end{array}$ & $\begin{array}{l}\text { Kabul } \\
\text { Kabul } \\
\text { Red } \\
\text { Red }\end{array}$ \\
\hline $\begin{array}{l}\text { Ürün Değerlendirmesi= } \\
\text { - Düşmanlık }\left(\mathrm{H}_{1}\right) \\
+ \text { GCA1 }\left(\mathrm{H}_{4 \mathrm{a}}\right) \\
+\mathrm{GCA} 2\left(\mathrm{H}_{4 \mathrm{~b})}\right.\end{array}$ & $\begin{array}{l}-, 281 \\
, 187 \\
, 122\end{array}$ & $\begin{array}{l}* * * \\
* * * \\
, 027^{*}\end{array}$ & $\begin{array}{l}\text { Kabul } \\
\text { Kabul } \\
\text { Kabul }\end{array}$ & $\begin{array}{l}-, 057 \\
, 457 \\
-, 096\end{array}$ & $\begin{array}{l}\text {,229 } \\
* * * \\
, 065\end{array}$ & $\begin{array}{l}\text { Red } \\
\text { Kabul } \\
\text { Red }\end{array}$ \\
\hline $\begin{array}{l}\text { GCA1= } \\
\text { - Düşmanlık }\left(\mathrm{H}_{2 \mathrm{a}}\right)\end{array}$ &,- 018 & ,729 & Red &,- 027 & ,604 & Red \\
\hline $\begin{array}{l}\text { GCA2 = } \\
\text { - Düşmanlık }\left(\mathrm{H}_{2 b}\right)\end{array}$ & -175 &, $003^{* *}$ & Kabul & -169 &, $003^{* *}$ & Kabul \\
\hline
\end{tabular}

$*^{*}:<0,05 \quad * *:<0,01 \quad * * *:<0,001$

Kolayda ürün: $(\chi 2 / \mathrm{df}=2,106 ; \mathrm{GFI}=, 910 ; \mathrm{CFI}=, 946 ; \mathrm{NFI}=, 902 ; \mathrm{IFI}=, 946 ; \mathrm{RMSEA}=0,47)$

Beğenmeli ürün: $(\chi 2 / \mathrm{df}=2,110 ; \mathrm{GFI}=, 908$; $\mathrm{CFI}=, 944 ; \mathrm{NFI}=, 900 ; \mathrm{IFI}=, 945 ; \mathrm{RMSEA}=, 047)$ 


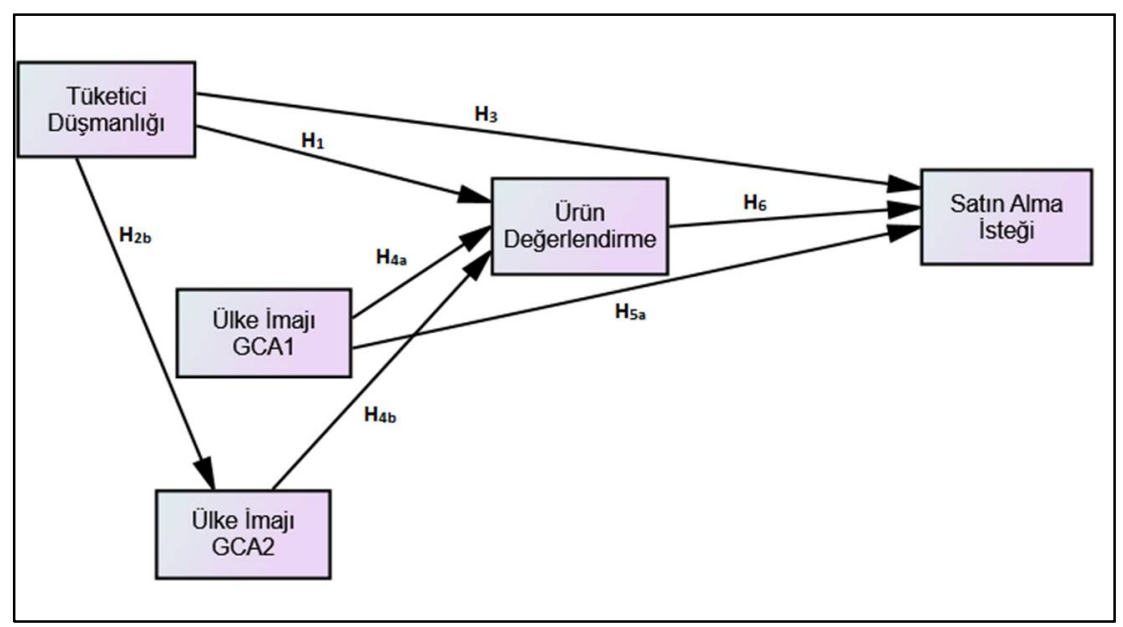

Şekil 2.1: Kolayda Ürün İçin Nihai Model

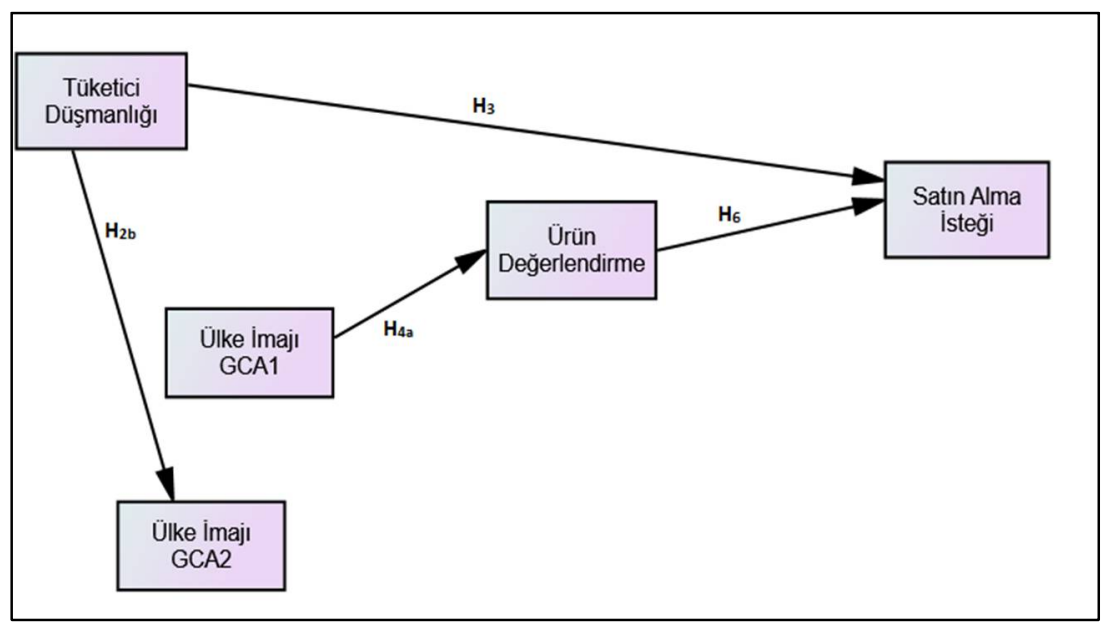

Şekil 2.2: Beğenmeli Ürün İçin Nihai Model

\section{DEĞERLENDİRME VE SONUÇ}

Uluslararası pazarlama faaliyetleri açısından büyük önem taşıyan tüketici düşmanlığının ülke imajı ve ürün değerlendirmesi üzerindeki etkilerini anlamayı amaçlayan bu çalıșma kapsamında öne sürülen araştırma modeli ve 9 hipotez hem kolayda ürün hem de beğenmeli ürün için sırasıyla ayrı ayrı test edilmiştir. Tüketici düşmanlığının ürün değerlendirmesi ve satın alma isteğiyle ilişkisini ortaya koyan çalışmalar iki farklı bakış açısını taşımaktadır. Klein vd. (1998) ve Klein (2002) tüketici düşmanlığının, bireyin satın alma isteğini, ürünü değerlendirmesinden bağımsız olarak 
doğrudan ve olumsuz şekilde etkilediğini göstermektedir. Diğer taraftan Baillargeon (2003)'e göre tüketici ürün değerlendirmesinde hem bilişsel hem de duygusal unsurlardan beslenmektedir. Bu noktada tüketiciler, etkiyi bilişten ayıramadıkları için tamamen objektif değerlendirmelerde bulunamamakta, böylelikle ürün değerlendirmeleri de olumsuz yönde gerçekleşmektedir. Bu bulgulardan hareketle çalışmada hem tüketici düşmanlığının ürün değerlendirmesini olumsuz yönde etkileyeceği üzerine $\left(\mathrm{H}_{1}\right)$ hem de satın alma isteğini olumsuz yönde etkileyeceği üzerine $\left(\mathrm{H}_{3}\right)$ iki hipotez kurulmuştur.

Kolayda ürünler için her iki hipotez de $\left(\mathrm{H}_{1}\right.$ ve $\left.\mathrm{H}_{3}\right)$ desteklenirken, beğenmeli ürünler açısından tüketici düşmanlığının sadece satın alma isteği üzerinde etkili olduğu $\left(\mathrm{H}_{3}\right)$ görülmüştür. Beğenmeli ürünlerin değerlendirilmesi kapsamında tüketici düşmanlığı etkili olmamıştır. Özetle, beğenmeli ürünlerde tüketici düşmanlığı ürün değerlendirmelerinden bağımsız olarak ve doğrudan satın alma isteği üzerinde etkili olmuştur. Hacıoğlu vd. (2013) de Türk tüketicilerin Fransız mallarına yönelik tutumlarına dair araştırmasında benzer şekilde düşmanlığın ürün değerlendirmesi üstünde etkili olmadığı sonucuna ulaşmışlardır. Bu bulgu, literatürde mevcut tüketici düşmanlığı modelini destekler niteliktedir (Klein vd.,1998; Klein, 2002). Bu model, tüketicilerin yabancı bir ürünü tüketici düşmanlığından dolayı almayabileceğini, ancak yine de ürün değerlendirmelerinin bu düşmanlıktan etkilenmeyeceğini (ürünü kaliteli olarak algılayabileceklerini) söylemektedir. Dolayısıyla beğenmeli ürün olarak seçilen cep telefonunun katılımcıların aşina oldukları ve Amerikan markası cep telefonlarının kalitesini değerlendirirken tüketici düşmanlığından etkilenmeden ürünü objektif olarak değerlendirdikleri, tüketici düşmanlığının da satın alma isteğinde devreye girdiği söylenebilir. Diğer taraftan ürün değerlendirmeleri tüketicinin bilişsel inançlarının yanı sıra duygularından da etkilenmektedir ki, özellikle saldırganlık (agresiyon) içeren duyguların uyarıcıya verilen tepkileri önemli ölçüde etkilediği bilinmektedir (Berkowitz vd., 2000). Dolayısıyla, gazlı içeceklerde tüketicilerin ürün değerlendirmelerini yaparken cep telefonlarında olduğu kadar objektif davranmadıkları, bu nedenle de duygularını (tüketici düşmanlığı) niyetlerinin yanı sıra ürün değerlendirmelerine de yansıttıkları düşünülebilir. Literatürde benzer bulgulara ulașıldığı görülmektedir (bkz. Riefler ve Diamantopoulos, 2007). Çalışmalardan birisi, bu durumun gıda ürünleri ve hizmetler kapsamında kültürle ilintili olabileceğini öne sürse de bu konuda net sonuçlar bulunmamaktadır.

Tüketici düşmanlığı ürün değerlendirmelerine benzer şekilde ülke imajı üzerinde de etkili olabilmektedir. Düşmanlık duyulan ülkenin imajının bu duygulardan etkilenmesi beklenen bir sonuçtur. Dolaysıyla, çalışmada tüketici düşmanlığının ülke imajının iki boyutu üzerinde de olumsuz yönde etkisi olacağına ilişkin $\mathrm{H}_{2 a}$ (GCA1) ve $\mathrm{H}_{2 b}$ (GCA2) hipotezleri oluşturulmuştur. Her iki ürün grubu için de sadece $\mathrm{H}_{2 b}$ hipotezi doğrulanmıştır. Bir başka deyişle, tüketici düşmanlığının ülke imajının insani boyutu üzerinde değil de benzerlik boyutu üzerinde etkili olduğu görülmüștür. Tüketici düşmanlığı ile ülke imajı arasındaki etkileşimleri inceleyen araştırmalar birbiriyle çelişkili sonuçlar ortaya koymaktadır (Klein, 2002). Örneğin, Klein vd. (1998) tüketicinin bir ülkeye karşı düşmanlık beslemesine rağmen, o ülkenin yüksek kalite ürünler ürettiğine inanabileceğini belirtmektedir. Tüketici tutumlarının tek boyutlu ya da 
homojen olmamasının bu duruma sebebiyet verebileceğini belirten Amine (2008), farklı şartlar altında farklı inançların devreye girerek aynı anda birbiriyle karşıt tutumlara yol açabileceğini ifade etmektedir. Dolayısıyla, çalışmada tüketici düşmanlığı ülke imajının insani boyutu üzerinde etkili olmazken, benzerlik boyutu üzerinde etkili olmuştur. Bir başka deyişle tüketiciler Amerikan vatandaşlarının çalışkanlığı, eğitim düzeyi veya teknik becerileri konusunda düşmanlık duygularından etkilenmemiş ve olumlu bir tutum sergilemişlerdir. Benzer bir bulguya Kiracı ve Kayabaşı'nın (2018) çalışmalarında da rastlanmaktadır. Söz konusu çalışmada, ABD’ye yönelik ekonomik düşmanlık en yüksek düzeyde iken insanlara karşı duyulan düşmanlığın en düşük ortalamaya sahip olduğu görülmektedir. Buna karşın, ülke imajının benzerlik boyutu tüketici düşmanlığından etkilenerek daha olumsuz bir tutum ortaya çıkarmıştır. Russell ve Russell (2006), çalışmalarında kültürel kimliği ön plana çıkartmanın, tüketici düşmanlığını daha etkili kılabileceğini göstermişlerdir. Benzerlik boyutu, tüketicilerin kendi kültürel kimliklerinin Amerika ile benzerliğini sorgulamakta, bu noktada da değerlendirmelerinde düşmanlık duygularından daha fazla etkilenmektedir.

Araştırma bulguları genellikle ülke imajının satın alma isteğini ürün değerlendirmesi ve ürüne yönelik tutum değișkenleri vasıtasıyla etkilediği yönündedir. Ancak aynı zamanda ülke imajının satın alma isteğini doğrudan etkilediğini ortaya koyan araştırma bulguları da mevcuttur (Maher ve Carter, 2011; Dagger ve Raciti, 2011; Sun ve Paswan, 2011; Kan vd., 2014). Buradan hareketle, ülke imajının hem yabancı ürün değerlendirmesini $\left(\mathrm{H}_{4 a}\right.$ ve $\left.\mathrm{H}_{4 b}\right)$ hem de satın alma isteğini $\left(\mathrm{H}_{5 a}\right.$ ve $\left.\mathrm{H}_{5 b}\right)$ olumlu yönde etkilediği öngörülmüştür.

Ülke imajı tüketicileri üç yoldan etkilemektedir (Amine, 2008); ürünün kalitesi vb. unsurlar açısından bilişsel olarak, semboller ve duygular aracılığıyla duygusal olarak ve tüketicinin sosyal ve kişisel normları aracılığıyla normatif olarak. Dolayısıyla bir ürünün değerlendirilmesinde tüketici, ülke imajını bu üç unsuru ipucu olarak kullanarak değerlendirmelerine dâhil eder. Çalışmada ülke imajının insan boyutunun (GCA1) yabancı ürün değerlendirmesini hem kolayda hem de beğenmeli ürünler için olumlu yönde etkilediği görülmüștür $\left(\mathrm{H}_{4 \mathrm{a}}\right)$. Bu bulgu ürünün kalitesine ipucu olan insan boyutunun bilișsel anlamda ürün değerlendirmelerinde kullanılması ile uyumludur. Diğer taraftan ülke imajının benzerlik boyutunun (GCA2) sadece kolayda ürünler için yabancı ürün değerlendirmesi üzerinde etkili olduğu görülmüştür $\left(\mathrm{H}_{4 b}\right)$. Tüketici psikolojisi literatürü, tüketicilerin dikkatini kültürel kimliklere çekmenin, tüketicilerin yerli ve yabancı ürünleri nasıl değerlendirdikleri üzerinde de etkisi olduğunu göstermektedir. Russell ve Russell (2006), tüketici düşmanlığının aktive edilmesiyle ön plana çıkartılan bir kültürel kimlik sorgulamasının, düşmanlık duyulan ülke ürünlerine karşı bir tepki yaratacağını öne sürmüş ve çalışmalarıyla bu öngörülerini desteklemişlerdir. Dolayısıyla bu çalışmada da düşmanlık duygusundan etkilenen ülke imajının yabancı ürün değerlendirmeleri üzerinde de etkili olduğu söylenebilecektir. Bu anlamda, tüketiciler ülke imajının benzerlik boyutunu (GCA2) duygusal ve normatif birer ipucu olarak kullanmış ve bunların etkisinde kalarak yabancl ürün değerlendirmelerini oluşturmuşlardır. Diğer taraftan, beğenmeli ürünlerde ise bu etki görülmemektedir. Bu durum da yine yukarıda bahsedildiği şekilde, beğenmeli ürünün 
değerlendirilmesi sürecinin daha çok bilişsel unsurlar üzerinden gerçekleştiği, duygusal unsurların sürece daha az dâhil edilmesinden kaynaklanabileceği düşünülmektedir.

Ülke imajının satın alma isteği üzerindeki etkilerine bakıldığında ise, sadece insan (GCA1) boyutunun kolayda ürünler açısından satın alma isteği üzerinde etkili olduğu görülmüştür. Öngörülen diğer ilișkiler anlamsız çıkmıştır. Literatürde ürün kategorisi-ülke imajı arasındaki uyum, etnosentrizm ve ürün kategorisi gibi unsurların ülke imajı ile satın alma isteği arasındaki ilişkiyi etkilediği görülmüştür (Sun ve Paswan, 2011). Dagger ve Raciti (2011) ülke imajı ile satın alma isteği arasındaki ilişkide tutarsızlığın ülke imajı-ürün imajı tutarsızlığından kaynaklandığını öne sürmüşlerdir. Çalışmada ülke ve ürün imajları arasında olumlu yönde ve güçlü bir uyumun varlığı halinde, ülke imajının satın alma isteği üzerinde olumlu bir etkisi olduğunu göstermişlerdir. Sun ve Paswan da (2011) çalışmalarında ülke imajı ile satın alma isteği arasında karmaşık bir ilişki olduğunu vurgulamışlardır. Çalışmalarında ülke imajının insan boyutunun satın alma isteğinin üzerinde daha tutarlı bir etkisi olduğunu göstermiş̧lerdir. Benzerlik boyutu açısından tutarlı bir bulguya ulaşılamamasını ise kültürel unsurlara dayandırmışlardır. Çalışmada Sun ve Paswan'ın (2011) çalışmasına benzer șekilde sadece insan boyutunun satın alma niyeti üzerinde etkili olduğu görülmüştür. Ancak bu ilişki de sadece kolayda ürün olan gazlı içeceklerde gözlenmiştir. Beğenmeli ürünler için bu ilişkinin gözlenmemesinin, ürün kategorisi-ülke imajı uyumsuzluğundan kaynaklanıyor olabileceği düşünülmektedir.

Son olarak, ürün değerlendirmesinin satın alma isteği üzerinde olumlu etkisi $\mathrm{H}_{6}$ hipotezi ile test edilmiş ve her iki ürün kategorisi için de bu ilişki desteklenmiştir. Her ne kadar Eren (2013) çalışmasında ürün değerlendirmesinin satın alma niyeti için önemli bir değiş̧ken olmadığı sonucuna varmış olsa da, bu çalışma kapsamında elde edilmiş olan bulgu beklendiği şekilde alanda yapılan geçmiş çalışmalarla uyumludur (Chinen vd., 2000; Hui ve Zhou, 2002; Orbaiz ve Papadopoulos, 2003).

Çalışma bulguları kolayda ve beğenmeli ürünler açısından tüketici düşmanlığının farklı etkilere yol açabileceğini göstermektedir. Tutum literatüründe duygu (emotion) ve düşüncelerin (cognition) birlikte hareket ederek tutumları oluşturdukları ifade edilmekle birlikte, kimi durumlarda duyguların kimi durumlarda ise düşüncelerin tutum oluşumunda daha etkili olduğu bilinmektedir (Erevelles, 1998). Örneğin, düşük ilgilenimli veya hedonik ürünler için duygular değerlendirme sürecinde daha baskın hale gelirken, yüksek ilgilenimli veya fonksiyonel ürünlerde ise düşüncelerin daha ön plana geçtiği bilinmektedir (Kempf, 1999; Ajzen, 2001; Geuens, vd., 2011). Dolayısıyla, seçilen ürün kategorisinin karar sürecinin duygu veya düşünce tabanlı olması, duyguların (tüketici düşmanlığının) süreçteki etkilerini farklılaştırmaktadır.

Duygu temelli karar sürecine sahip ürün kategorilerinde, duygular sürece daha fazla hâkim olmaktadır. Çalışmada seçilen kolayda ürün de (gazlı içecekler) bu anlamda duygu temelli bir karar süreci olarak değerlendirilebilecektir. Buradan hareketle kolayda ürün bağlamında, tüketici düșmanlığının satın alma isteğini hem doğrudan hem de tutumlar (ülke imajı ve ürün değerlendirmeleri) üzerinden etkilediği görülmektedir. Yani tüketiciler, ülkeye ve ürüne yönelik tutumları açısından da düşmanlık duygularının etkisinde kalmaktadır. Diğer taraftan, beğenmeli ürün ise (cep telefonu) düşünce temelli bir karar süreci olarak değerlendirilebilecektir. Buradan hareketle beğenmeli ürün 
bağlamında, tüketici düşmanlığının tutumlar üzerinde değil, sadece satın alma niyeti üzerinde doğrudan bir etkisi olduğu görülmektedir. Bir başka deyişle, bu ürün kategorisinde bilişsel ve duygusal süreçler birbirinden tamamen ayrı işlemiş (Zajonc ve Markus'un (1982) bağımsızlık hipotezi ile benzer şekilde), tutumlar bilişsel temelde oluşturulurken, duygular doğrudan satın alma niyeti üzerinde etkili hale gelmiştir. Yani tüketiciler, ürünü değerlendirirken düşmanlık duygularından etkilenmemişler ve ancak satın alma niyeti aşamasında düşmanlık etkili hale gelmiştir. Literatürde, tüketici düşmanlığının ürün kategorileri bağlamında etkilerini inceleyen çalışmalar çelişkili sonuçlar ortaya koyduğundan, çalışmada ortaya çıkan bu ilişki yapısının sonraki çalışmalara yol göstermek açısından literatüre katkı sağlayacağı düşünülmektedir. Ayrıca, tüketici düşmanlığı literatüründe kolayda ürünlere yönelik az sayıda çalıșma bulunmaktadır ve ağırlıklı olarak ilgilenim düzeyi yüksek veya beğenmeli ürünler üzerinden çalışmalar yapıldığı görülmektedir (Riefler ve Diamantopoulos, 2007). Türkiye'de gerçekleştirilen çalışmalarda ise herhangi bir ürün türü ya da kategorisine yer verilmediği görülmektedir (Akdoğan vd., 2012; Eren, 2013; Hacıŏ̆lu vd., 2013; Kiracı ve Kayabaşı, 2018). Dolayısıyla, farklı ürün türleri ya da ilgilenim düzeylerinin tüketici düşmanlığı, ülke imajı, ürün değerlendirmeleri ve satın alma isteği üzerindeki etkilerinin daha detaylı incelenmesi literatüre katkı sağlayacaktır.

Elde edilen bulgular uygulama açısından da önemli ipuçları sağlamaktadır. Beğenmeli ürünlerde ürünün değerlendirilmesi açısından düşmanlık duygusu etkili olmadı̆̆ından, marka imajı da önemli bir aşınmaya uğramayacaktır. Dolayısıyla, eğer ki tüketicinin ürün değerlendirmesine yönelik tutumu düşmanlık duygularının üstüne çıkartılabilirse, satın alma isteği de olumlu olabilecektir. Ayrıca bu işletmelerin düşmanlık yaşanan uluslararası pazarlarda ürün ve marka imajlarını güçlendirecek iddialara ağırlık vermeleri önem taşımaktadır. Ancak, duygu temelli karar verilen ürün kategorilerinde düşmanlık duyguları tutumları da etkilediğinden, sonuçları daha uzun vadeli olarak marka ve ülke imajına da zarar verebilecektir. Dolayısıyla, yaşanan düşmanlık ortadan kalksa ya da azalsa bile tüketici belleğinde bu tutumlar saklanacağından satın alma isteği olumsuz etkilenmeye devam edecektir. Duygu temelli oluşan tutumların bellekten daha hızlı çağrıldığı bilinmektedir. Bu nedenle de tüketici bu tür ürün ve markalara yönelik oluşturduğu tutumları sorgulamadan belleğinden çağırma ve karar sürecinde kullanma eğiliminde olacaktır. Bu nedenle, bu tür ürünlere yönelik pazarlama stratejilerinde düşmanlık duygusunu azaltmaya yönelik ya da bu duyguyu dengeleyecek başka duyguları etkileyerek tutumların değiştirilmesine çaba harcanmalıdır.

Araştırma örnekleminin zaman, maliyet ve insan kaynakları unsurlarından ötürü, tesadüfî olmayan örnekleme yöntemlerinden faydalanılarak belirlenmiş oluşu çalışmanın temel kısıtını oluşturmaktadır. Ayrıca çalışmaya sadece Karamanoğlu Mehmetbey Üniversitesi İ̉BF öğrencilerinin dâhil edilmesi de çalışmaya ilişkin diğer bir kısıttır. Son olarak, ülkeler izledikleri ekonomik ve siyasi politikalar sonucu uluslararası arenada sürekli farklı pozisyonlar alabilmekte, bu durumun doğal bir sonucu olarak diğer ülkelerle olan ilişkilerinde yakınlaşmalar veya uzaklaşmalar yaşanabilmektedir. Nitekim çalışma kapsamında incelenmiş olan Türkiye-Amerika arasındaki ilişki de bu bağlamda konjonktürel bir yapıda olduğundan, elde edilen sonuçlar genellenebilirlikten 
Sevgi Ayșe Öztürk, Fatma Zeynep Özata, Fuat Erol, “Tüketici Düşmanlığının Ülke İmajı, Ürün Değerlendirme ve Yabancı Ürün Satın Alma İsteğine Etkisi Üzerine Bir Araştırma”, İstanbul Gelişim Üniversitesi Sosyal Bilimler Dergisi, 6 (1), Nisan 2019, ss. 76-101

uzak, dönemsel sonuçlar sağlayacaktır. Bu durum ise çalışmaya ilişkin bir diğer kısıt olarak karşımıza çıkmaktadır.

\section{KAYNAKÇA}

AAKER, D. (1991). Managing brand equity: Capitalizing on the value of a brand name. Free Press, New York.

AJZEN, I. (2001). Nature and operations of attitudes. Annual Review of Psychology, 52(1), 27-58.

AKDOGAN, M. S., KAPLAN, M., OZGENER, S. ve COSKUN, A. (2012). The effects of consumer ethnocentrism and consumer animosity on the re-purchase intent: The moderating role of consumer loyalty. Emerging Markets Journal, 2(1), 1-12.

ALLEN, P. ve BENNETT, K. (2010). Pasw statistics by SPSS: A practical guide. 18'th Edition, Cengage Learning, Australia.

AMINE, L. S. (2008). Country-of-Origin, animosity and consumer response: Marketing implications of anti-Americanism and francophobia. International Business Review, 17, 402-422.

ANG, S. H., JUNG, K., KAU, A. K., LEONG, S. M., PORNPITAKPAN, C. ve TAN, S. J. (2004). Animosity toward economic giants: What the little guys think. Journal of Consumer Marketing, 21(3), 190-207.

BAILLARGEON, J. C. L. (2003). Product-Country images in the Argentine setting: An analysis of animosity and admiration. (Unpublished Master's Thesis), Carleton University, Canada.

BAKER, M. J. ve CHURCHILL, G. A. Jr. (1977). The impact of physically attractive models on advertising evaluations. Journal of Marketing Research, 14, 538-555.

BALABANIS, G., DIAMANTOPOILOS, A., MUELLER, R. D. ve MELEWAR, T. C. (2001). The impact of nationalism, patriotism, and internationalism on consumer ethnocentric tendencies. Journal of International Business Studies, 32(1), 157-175.

BALABANIS, G., MUELLER, R. ve MELEWAR, T. C. (2002). The human values' lenses of country of origin images. International Marketing Review, 19(6), 582-610.

BERKOWITZ, L., JAFFEE, S., JO, E. ve TROCCOLI, B. T. (2000). On the correction of feeling-induced judgmental biases feeling and thinking: The role of affect in social cognition. (Ed: J.P. Forgas), Cambridge, UK: Cambridge University Press, 131-152.

BROWNE, M. W. ve CUDECK, R. (1992). Alternative ways of assessing model fit. Sociological Methods \& Research, November, 230-258.

CARTER, L. L. (2009). Consumer receptivity of foreign products: The roles of country-of-origin image, consumer ethnocentrism and animosity. (Unpublished Doctor of Philosophy Thesis), Old Dominion University, Business Administration.

CENGIZ, E. (2009). Tüketicilerin ürün tercihinde rol oynayan ürün menșeinin, marka, fiyat ve kalite değişkenleri açısından incelenmesi. Atatürk Üniversitesi İktisadi ve Ídari Bilimler Dergisi, 23(2), 155-171. 
Sevgi Ayșe Öztürk, Fatma Zeynep Özata, Fuat Erol, “Tüketici Düşmanlığının Ülke İmajı, Ürün Değerlendirme ve Yabancı Ürün Satın Alma İsteğine Etkisi Üzerine Bir Araştırma”, İstanbul Gelișim Üniversitesi Sosyal Bilimler Dergisi, 6 (1), Nisan 2019, ss. 76-101

CERVINO, J., SANCHEZ, J. ve CUBILLO, J. M. (2005). Made in effect, competitive marketing strategy, and brand performance: An analysis for Spanish brands. Journal of American Academy of Business, 6(2), 237-244.

CHAN, T. S., CHAN, K. K. ve LEUNG, L. C. (2010). How consumer ethnocentrism and animosity impair the economic recovery of emerging markets. Journal of Global Marketing, 23(3), 208-225.

CHINEN, K., JUN, M. ve HAMPTON, G. M. (2000). Product quality, market presence, and buying behavior: Aggregate images of foreign products in the U.S. Multinational Business Review, 29-38.

CUI, A. P., WAJDA, T. A. ve HU, M. Y. (2012). Consumer animosity and product choice: Might price make a difference? Journal of Consumer Marketing, 29(7), 494-506.

DAGGER, T. S. ve RACITI, M. M. (2011). Matching consumers' country and product image perceptions: an Australian perspective. Journal of Consumer Marketing, 28(3), 200-210.

DARLING, J. R. ve ARNOLD, D. R. (1988). The competitive position abroad of products and marketing practices of the United States, Japan, and selected European countries. Journal of Consumer Marketing, 5, 61-68.

DARLING, J. R. ve WOOD, V. R. (1990). A longitudinal study comparing perceptions of U.S. and Japanese consumer products in a third/neutral country: Finland 1975 to 1985. Journal of International Business Studies, 21(3), 427-450.

DICHTER, E. (1962). The world customer. Harvard Business Review, 40(4), 113122.

DING, L., VELICER, W. F. ve HARLOW, L. L. (1995). Effects of estimation methods, number of indicators per factor and improper solutions on structural equation modeling fit indices. Structural Equation Modeling, 2, 119-143.

DODDS, W. B., MONROE, K. B. ve GREWAL, D. (1991). The effects of price, brand, and store information on buyer's product evaluations. Journal of Marketing Research, 28, 307-319.

EREN, S. S. (2013). Young consumers' attitudes toward American products. Procedia - Social and Behavioral Sciences, 99, 489-495.

EREVELLES, S. (1998). The role of affect in marketing. Journal of Business Research, 42(3), 199-215.

FETTAHLIOĞLU, S. ve SÜNBÜL, M. B. (2015). Tüketici etnosentrizmi ve tüketici husumetinin X, Y, Z kuşakları açısından incelenmesi. International Journal of Academic Value Studies, 1(1), 26-45.

FIELD, A. P. (2009). Discovering statistics using SPSS. 3th Edition, Sage, London.

FISHBEIN, M. ve AJZEN, I. (1975). Belief, attitude, intention and behavior: An introduction to theory and research. Reading, MA: Addison-Wesley.

FORNELL, C. ve LARCKER, D. F. (1981). Evaluating structural equation models with unobservable variables and measurement error. Journal of Marketing Research, 18(1), 39-50.

GEUENS, M., De PELDMACKER, P. ve FASEUR, T. (2011). Emotional advertising: Revisiting the role of product category. Journal of Business Research, 64(4), 418-426. 
Sevgi Ayșe Öztürk, Fatma Zeynep Özata, Fuat Erol, “Tüketici Düşmanlığının Ülke İmajı, Ürün Değerlendirme ve Yabancı Ürün Satın Alma İsteğine Etkisi Üzerine Bir Araştırma”, İstanbul Gelişim Üniversitesi Sosyal Bilimler Dergisi, 6 (1), Nisan 2019, ss. 76-101

HACIOĞLU, G., EREN, S. S., KURT, G. ve ÇELIKKKAN, H. (2013). Tüketicilerin düşmanlık hissi ve etnik merkezciliği ile satın alma niyeti arasındaki ilişkiler: Türk tüketicilerin Fransız malı ürünlere yönelik tutumlarına dair bir araştırma. 18. Ulusal Pazarlama Kongresi, Kars, 576-585.

HAIR, J. F., BLACK, W. C., BABIN, B. J. ve ANDERSON, R. E. (2013). Multivariate data analysis. 7th Edition, Pearson, America.

HESLOP, L. A., LU, I. R. R. ve CRAY, D. (2008). Modeling country image effects through an international crisis. International Marketing Review, 25(4), 354-378.

HONG, S. ve WYER, R. S. (1990). Determinants of product evaluation: Effects of the time interval between knowledge of a product's country of origin and information about its specific attributes. Journal of Consumer Research, 17(3), 277-288.

HUANG, Y., PHAU, I. ve LIN, C. (2010). Consumer animosity, economic hardship, and normative influence: How do they affect consumers' purchase intention? European Journal of Marketing, 44(7/8), 909-937.

HUI, M. K. ve ZHOU, L. (2002). Linking product evaluations and purchase intention for country-of-origin effects. Journal of Global Marketing, 15(3/4), 95-116.

Hürriyet. (2003). ABD ve İngiliz mallarına boykot kampanyası. 17.04.2018 tarihinde http://www.hurriyet.com.tr/gundem/abd-ve-ingiliz-mallarina-boykotkampanyasi-38447313 adresinden alınmıştır.

ISHII, K. (2009). Nationalistic sentiments of Chinese consumers: The effects and determinants of animosity and consumer ethnocentrism. Journal of International Consumer Marketing, 21(4), 299-308.

JUNG, K., S. H. ANG, S. M. Leong, TAN, S. J., PORPITAKPAN, C. ve KAU, A. K. (2002). A typology of animosity and its cross-national validation. Journal of Cross-Cultural Psychology, 33(6), 525-539.

KAN, G., CLIQUET, G. ve GALLO, M. P. (2014). The effect of country image on hypermarket patronage intention. International Journal of Retail \& Distribution Management, 42(2), 106-130.

KELLER, K. (2003). Brand synthesis: The multidimensionality of brand knowledge. Journal of Consumer Research, 29, 595-600.

KEMPF, D. S. (1999). Attitude formation from product trial: Distinct roles of cognition and affect for hedonic and functional products. Psychology and Marketing, 16(1), 35-50.

KILBOURNE, W. E. (1986). An exploratory study of sex role stereotyping on attitudes toward magazine advertisements. Journal of the Academy of Marketing Science, 14(4), 43-46.

KIRACI, H. (2017). Ülkeler arasındaki düşmanlıkların tüketicilere yansıması: Tüketici düşmanlığı kavramı üzerine kavramsal bir çalışma. Journal of Human Sciences, 14(2), 1711-1735.

KIRACI, H. ve KAYABAȘI, A. (2018). Tüketicilerin hissettikleri farklı düşmanlık türlerinin satın almama niyeti üzerindeki etkisi: Türk tüketicilerinin Amerika düşmanlığı üzerine bir araștırma. Pamukkale Üniversitesi Sosyal Bilimler Enstitüsü Dergisi, 31, 203-214. 
KLEIN, J. G. (2002). Us versus them, or us versus everyone? Delineating consumer aversion to foreign goods. Journal of International Business Studies, 33(2), 345-363.

KLEIN, J. G., ETTENSON, R. E. ve MORRIS, M. D. (1998). The animosity model of foreign product purchase: An empirical test on the People's Republic of China. Journal of Marketing, 62 (1), 89-100.

KOUBAA, Y. (2008). Country of origin, brand image perception, and brand image structure. Asia Pacific Journal of Marketing and Logistics, 20(2), 139-155.

LADA, S., SIDIN, S. M. D. ve CHENG, K. T. G. (2014). Moderating role of product involvement on the relationship between brand personality and brand loyalty. Journal of Internet Banking and Commerce, 19(2), 1-16.

LALA, V., ALLRED, A. T. ve CHAKRABORTY, G. (2009). A multidimensional scale for measuring country image. Journal of International Consumer Marketing, 21(1), 51-66.

LEONG, S. M., COTE, J. A., ANG, S. H., TAN, S. J., JUNG, K., KAU, A. K. ve Pornpitakpan, C. (2008). Understanding consumer animosity in an international crisis: Nature, antecedents, and consequences. Journal of International Business Studies, 39, 996-1009.

MAHER, A. A. ve CARTER, L. L. (2011). The affective and cognitive components of country image: Perceptions of American products in Kuwait. International Marketing Review, 28(6), 559-580.

MOLLA, A. (2009). Soğuk savaş sonrası Körfez Krizleri ve Türkiye ABD NATO ilişkileri. Akademik Fener, 29-45.

MUTLU, H. M., ÇEVIKER, A. ve ÇİRKIN, Z. (2011). Tüketici etnosentrizmi ve yabancı ürün satın alma niyeti: Türkiye ve Suriye üzerine karşllaştırmalı analiz. Sosyo Ekonomi, 51-74.

NAGASHIMA, A. (1970). A comparison of Japanese and U.S. attitudes toward foreign products. Journal of Marketing, 34(1), 68-74.

NAGASHIMA, A. (1977). A comparative "made in" product image survey among Japanese businessmen. Journal of Marketing, 41(3), 95-100.

NIJSSEN, E. J. ve DOUGLAS, S. P. (2004). Examining the animosity model in a country with a high level of foreign trade. International Journal of Research in Marketing, 21(1), 23-38.

OKECHUKU, C. ve WANG, G. (1988). The effectiveness of Chinese print advertisements in North America. Journal of Advertising Research, 28, 25-34.

ORBAIZ, L. V. ve PAPADOPOULOS, N. (2003). Toward a model of consumer receptivity of foreign and domestic products. Journal of International Consumer Marketing, 15(3), 101-126.

ÖZDAMAR, K. (2004). Paket programlar ve istatistiksel veri analizi 1.1. Baskl, Kaan Kitapevi, Eskişehir.

ÖZER, A. ve DOVGANIUUC, O. (2013). Gösteriş amaçlı ürünlerin satın alınmasında ülke orijini ve tüketici etnosentrizmi etkisi. Pazarlama ve Pazarlama Araştırmaları Dergisi, 11, 61-80.

ÖZTÜRK, S. A., DOĞAN ÇIFTÇI, S., ABBAS, M., ÖGEL, S. ve GÜMÜŞ, C. (2017). Bilmek mi sevmek mi? Bilişsel ve duygusal ülke imajının ürün imajı ve satın alma 
niyetindeki etkisi üzerine kültürler arası bir çalışma. Pazarlama ve Pazarlama Araştırmaları Dergisi, 19, 79-102.

PAPADOPOULOS, N., HESLOP, L. A. ve the IKON Research Group (2000). A crossnational and longitudinal study of product-country images with a focus on the U.S. and Japan. Marketing Science Institute Report, 00-106: 67.

PARAMESWARAN, R. ve PISHARODI, M. R. (2002). Assimilation effects in country image research. International Marketing Review, 19, 259-278.

PARAMESWARAN, R. ve PISHARODI, R. M. (1994). Facets of country of origin image: An empirical assessment. Journal of Advertising, 23(1), 43-56.

PEREIRA, A., HSU, C. C. ve KUNDU, S. K. (2005). Country-of-Origin image: Measurement and cross-national testing. Journal of Business Research, 58, 103-106.

PETERSON, R. A. ve JOLIBERT, A. J. P. (1995). A meta-analysis of country-oforigin effects. Journal of International Business Studies, 26(4), 883-900.

PHARR, J. M. (2005). Synthesizing country-of-origin research from the last decade: is the concept still salient in an era of global brands? Journal of Marketing Theory and Practice, 13(4), 34-45.

PISHARODI, R. M. ve PARAMESWARAN, R. (1992). Confirmatory factor analysis of a country-of-origin scale: initial results. Advances in Consumer Research, 19, 706-714.

PODOSHEN, J. S. (2005). Acculturation, ethnic conflict and equity theory: The American Jewish consumer. (Unpublished Ph.D. Dissertation), Temple University.

RIEFLER, P. ve DIAMANTOPOULOS, A. (2007). Consumer animosity: A literature review and a reconsideration of its measurement. International Marketing Review, 24(1), 87-119.

ROSE, M., ROSE, G. M. ve SHOHAM, A. (2009). The impact of consumer animosity on attitudes towards foreign goods: A study of Jewish and Arab Israelis. Journal of Consumer Marketing, 26(5), 330-339.

ROTH, K. P. ve DIAMANTOPOULOS, A. (2009). Advancing the country image construct. Journal of Business Research, 62(7), 726-740.

RUSSELL, D.W. ve RUSSELL, C.A. (2006). Explicit and implicit catalysts of consumer resistance: The effects of animosity, cultural salience and country-of-origin on subsequent choice. International Journal of Research in Marketing, 23(3), 321-331.

SCHOOLER, R. (1971). Bias phenomena attendant to the marketing of foreign goods in the U.S. Journal of International Business Studies, 2(1), 71-80.

SHIMP, T. A. (1984). Consumer ethnocentrism - the concept and a preliminary empirical test. Advances in Consumer Research, 11, 285-290.

SHIMP, T. A., DUNN, T. H. ve KLEIN, J. G. (2004). Remnants of the U.S. Civil War and modern consumer behavior. Psychology and Marketing, 21, 75-92.

SHIN, M. (2001). The animosity model of foreign product purchase revisited: Does it work in Korea. Journal of Empirical Generalisations in Marketing Science, 6(1), 114.

SHOHAM, A., GAVISH, Y. ve ROSE, G. M. (2016). Consequences of consumer animosity: A meta-analytic integration. Journal of International Consumer Marketing, 28(3), 185-200. 
SUN, Q. ve PASWAN, A. (2011). Country branding using product quality. Journal of Brand Management, 19(2), 143-157.

TIAN, S., ve PASADEOS, Y. (2012). A revised model of animosity: The impact of anti-Japanese sentiment on consumer behavior in China. Journal of Current Issues \& Research in Advertising, 33(2), 170-191.

TINSLEY, H. E. ve TINSLEY, D. J. (1987). Uses of factor analysis in counseling psychology research. Journal of Counseling Psychology, 34(4), 414-424.

TÜİK. (2018). 22.01.2018 tarihinde http://www.tuik.gov.tr/UstMenu.do ?metod=temelist adresinden alınmıștır.

ULGADO, F. M. ve LEE, M. (1998). The Korean versus American marketplace: Consumer reactions to foreign products. Psychology \& Marketing, 15(6), 595-614.

ÜNAL, S. (2017). The mediating role of product familiarity in consumer animosity. Journal of Accounting \& Marketing, 6(4), 1-11.

VERLEGH, P. W. J. ve STEENKAMP, J-B. E. M. (1999). A review and meta-analysis of country-of-origin research. Journal of Economic Psychology, 20(5), 521-546.

WOOD, V. R. ve DARLING, J. R. (1993). The marketing challenges of the newly independent republics: Product competitiveness in global markets. Journal of International Marketing, 1(1), 77-102.

ZAJONC, R. B. (1980). Feeling and thinking: Preferences need no inferences. American Psychologist, 35(2), 151-175.

ZAJONC, R. B. ve MARKUS, H. (1982). Affective and cognitive factors in preferences. Journal of Consumer Research, 9(2), 123-131.

\section{Summary}

Because of the phenomenon of globalization and developments in the information technologies, the physical boundaries between countries have begun to wipe out and these developments have made international business and international marketing activities more widespread than ever. Despite these developments, not all obstacles in front of international trade have removed. Thus, the individuals who are at the center of all these developments can consider many variables in purchasing decisions beyond the physical possibilities. For this reason, it is important to understand issues such as consumer animosity, country image and product evaluation which have an important place in individuals' willingness to buy foreign products. Though there are numerous studies on these concepts, it is seen in the literature that these structures have contradictory results in relation to each other. Since some studies have revealed that consumer animosity has direct effect on buying decision while some other studies have put forward the results proving that, consumer animosity, as an emotion, also has effect on various buying decision variables such as country image and product evaluation. It is foreseen that these findings come from product and country related factors. For that reason, this study was aimed to explain Turkish consumers' willingness to buy American made convenience and shopping goods and the relationship between their country image, product evaluation and consumer animosity. In addition, it was aimed to determine whether there are differences in terms of 
product groups and to achieve more generalized results by moving from two different product groups which are convenience and shopping goods. For these purposes, literature review conducted on consumer animosity, country image, product evaluation and the willingness to buy and in the light of the information obtained, nine hypotheses and research model were developed. Hypotheses were tested separately for both convenience and shopping goods. As a result, the effect of the human dimension of the country image on willingness to buy and the effects of consumer animosity and similarity dimension of the country image on product evaluation were found to have significant differences in terms of product groups. Also, for both product groups; the effect of consumer animosity and product evaluation on willingness to buy; the effect of human dimension of the country image on product evaluation and the effect of animosity on similarity dimension of the country image were seen significant. Surprisingly while hypothesis about the relation between animosity and similarity dimension of the country image were verified, the hypothesis for animosity and human dimension of the country image were rejected. In this context, while some obtained results confirming previous studies, others helping to gain new theoretical perspectives for future studies. Obtained findings also provide important clues for practitioners. Since the sense of animosity is not effective on evaluation of the product for shopping goods, the brand image will not be subjected to a significant erosion. Therefore, if the consumer's attitude towards product evaluation can be surpassed by animosity, the willingness to buy can also be positive. In addition, it is important for these companies to make an assertive commitment to strengthen product and brand image in hostile international markets. However, since animosity also affects attitudes in emotionalbased decision-making product categories, the results may be detrimental to brand and country image with longer term results. For this reason, marketing strategies for such products should aim to reduce animosity or try to change attitudes by affecting other emotions which will balance the animosity.

\section{EK-1: Ankette Yer Alan Ölçeklere Ait İfadeler Tüketici Düşmanlığı Ölçeği Iffadeleri;}

- ABD'yi sevmiyorum.

- ABD’ye karşı kızgın hissediyorum.

- Türkiye'ye tutumu nedeniyle ABD’yi affetmeyeceğim.

- $\quad$ ABD’yi, güvenilir bir ticaret ortağı olarak görmüyorum.

- $\quad \mathrm{ABD}$, Türkiye üzerinden ekonomik güç kazanmak istiyor.

- $\quad A B D$, Türkiye'den istifade ediyor.

- $\quad$ ABD, Türkiye'de çok fazla ekonomik etkiye sahip.

- $\quad$ ABD, Türkiye ile adil olmayan bir şekilde iş yapmakta.

\section{Ülke İmajı Ölçeği Ífadeleri;}

- İnsanları iyi eğitimlidir.

- İnsanları çalıșkandır.

- İnsanlar yüksek standartlara ulaşmaktan gurur duyarlar.

- Ülkedeki yaşam standartları yüksektir. 
- İ̇şücünün teknik becerileri yüksektir.

- ABD ile benzer politik görüşlerimiz var.

- $\quad$ ABD ile ekonomik olarak benzeriz.

- $\quad$ ABD ile kültürlerimiz benzerdir.

Ürün Değerlendirmesi Ölçeği İfadeleri;

- Dikkatli bir şekilde üretilmiştir ve iyi bir işçiliğe sahiptir.

- Genellikle diğer ülkelerde üretilen benzer ürünlerden daha yüksek kaliteye sahiptir.

- Genellikle renk ve dizayn açısından daha üstün özelliklere sahiptir.

- Üstün ve gelişmiş bir teknolojiye sahiptir.

- Genellikle oldukça dayanıklıdır ve istenildiği müddetçe kullanılabilir.

- Ödenen paraya değer.

Satın Alma İsteği Ölçeği İfadeleri;

- Eğer ABD kökenli bir cep telefonu satın alırsam, kendimi suçlu hissederim.

- Asla ABD kökenli bir cep telefonu satın almak istemem.

- Mümkün oldukça, ABD kökenli cep telefonlarını satın almaktan kaçınırım.

- ABD kökenli bir cep telefonuna sahip olma fikrinden hoşlanmam.

- $\quad$ Eğer iki ürün eşit kaliteye sahipse, başka bir ülke kökenli ürünü almayı tercih ederim. 